\title{
Inflation Targeting and Exchange Rate Rules in an Open Economy
}

Eric Parrado 


\title{
IMF Working Paper
}

Monetary and Financial Systems Department

\section{Inflation Targeting and Exchange Rate Rules in an Open Economy}

\author{
Prepared by Eric Parrado ${ }^{1}$ \\ Authorized for distribution by David Marston
}

February 2004

\begin{abstract}
This Working Paper should not be reported as representing the views of the IMF. The views expressed in this are those of the author(s) and do not necessarily represent those of the IMF or IMF policy. describe research in progress by the author(s) and are published to elicit comments and to further debate.

This paper provides a simple dynamic neo-Keynesian model that can be used to analyze the impact of monetary policy that considers inflation targeting in a small open economy. This economy is characterized by imperfect competition and short-run price rigidity. The main findings of the paper are that, depending on what shocks affect the economy, the effects of inflation targeting on output and inflation volatility depend crucially on the exchange rate regime and the inflation index being targeted. First, in the presence of real shocks, flexible exchange rates dominate managed exchange rates, while for nominal shocks the reverse is true. Second, domestically generated inflation targeting is preferable to CPI inflation targeting, because the former is more stabilizing not only in relation to both measures of inflation, but also to the output gap and the real exchange rate. Finally, flexible inflation targeting outperforms strict inflation targeting in terms of welfare.
\end{abstract}

JEL Classification Numbers: E52, E58, F41

Keywords: inflation targeting, open economy, exchange rates, monetary policy rules Author's E-Mail Address: eparrado@imf.org

\footnotetext{
${ }^{1}$ I thank Mark Gertler and Andrés Velasco for valuable recommendations. I also appreciate useful suggestions from William Baumol, Ricardo Caballero, Andrés Escobar, Raquel Fernández, Jordi Galí, Esteban Jadresic, Boyan Jovanovic, Tommaso Monacelli, Paulina Nazal, Mark Stone, Lars Svensson, and seminar participants at the Central Bank of Chile, the Lacea Winter Camp, the Federal Reserve Bank of San Francisco, New York University, and the University of Chile (CEA). I thank Natalie Baumer for useful editorial assistance.
} 


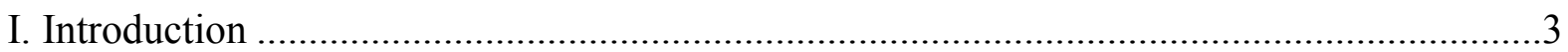

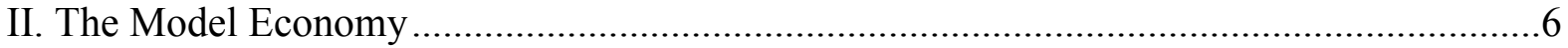

A. Microeconomic Foundations of Demand and Supply......................................6

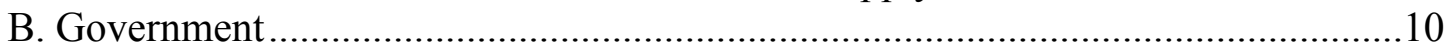

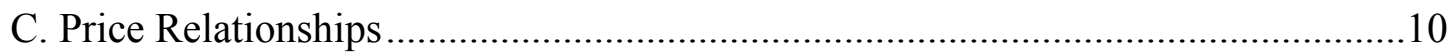

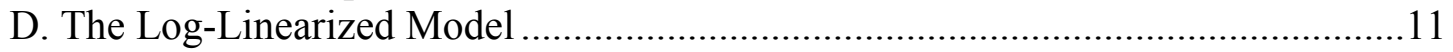

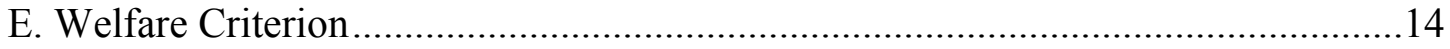

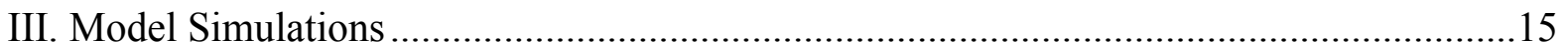

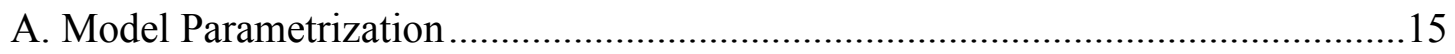

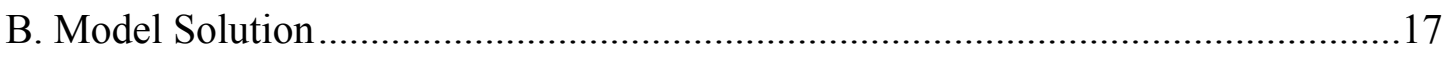

IV. Results and Comparisons.................................................................................... 18

A. Flexible Versus Managed Exchange Rates .................................................... 18

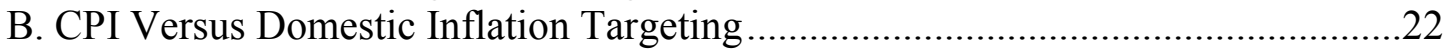

C. Flexible Versus Strict Inflation Targeting.........................................................24

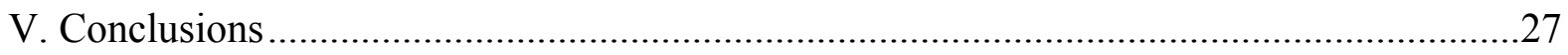

Appendices

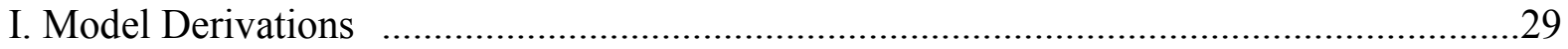

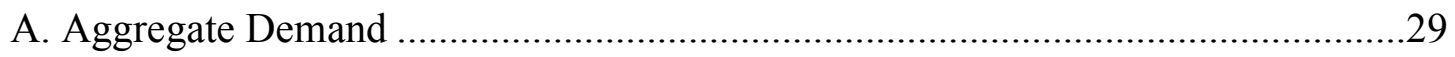

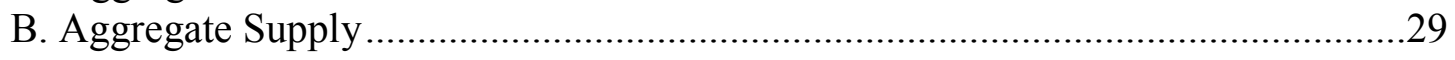

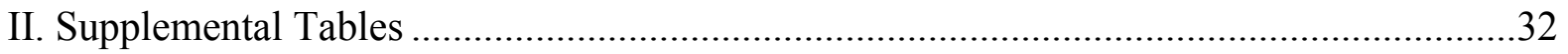

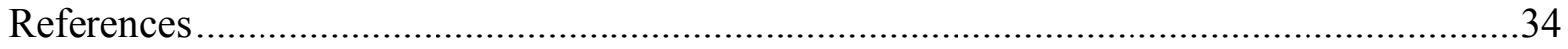

Tables

1. GMM Estimations of the Central Bank of Chile's Reaction Function ....................16

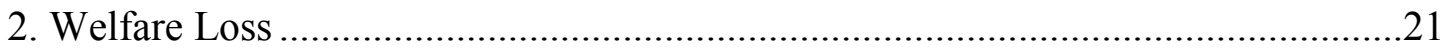

Appendix Tables

A.1. Unconditional Standard Deviations: Foreign Interest Rate Shock .....................32

A.2. Unconditional Standard Deviations: Foreign Output Shock...............................32

A.3. Unconditional Standard Deviations: Productivity Shock ...................................33

A.4. Unconditional Standard Deviations: Domestic Interest Rate Shock ..................33

Figures

1. Flexible vs. Managed Exchange Rate: Domestic Inflation Targeting ....................19

2. Flexible vs. Managed Exchange Rate: CPI Inflation Targeting ............................20

3. CPI vs. Domestic Inflation Targeting: Flexible Exchange Rate ..............................22

4. CPI vs. Domestic Inflation Targeting: Managed Exchange Rate ............................23

5. Flexible vs. Strict CPI Inflation Targeting: Flexible Exchange Rate .......................25

6. Flexible vs. Strict Domestic Inflation Targeting: Flexible Exchange Rate .............26 


\section{INTRODUCTION}

After many discussions and debates, researchers and policymakers seem to be converging on the idea that inflation targeting is a central ingredient of a sound monetary policy. They argue that monetary policy works best if central banks have a nominal anchor to guide policy and to tie down inflationary expectations. Small open economies, specifically emerging economies, would probably want to replicate the recipe from relatively successful experiences. This paper develops a framework to analyze this question within a context suited for these economies.

This study provides a simple dynamic neo-Keynesian model that is intended to analyze the impact of monetary policy with inflation targeting in a small open economy. ${ }^{2}$ The paper addresses the differences in economic volatility and welfare of: (1) having flexible versus managed exchange rates; (2) targeting the consumer price index (CPI) inflation versus domestic inflation, ${ }^{3}$ and (3) implementing strict versus flexible inflation targeting. ${ }^{4}$ In this way, the successful regime is the one that stabilizes the economy in response to several random disturbances. In particular, the criterion for choosing between regimes and/or targets is the minimization of output, inflation, and real exchange rate volatility, and consequently lower social loss. The paper attempts to explain some key differences in the way monetary policy is conducted and how these differences contribute to macroeconomic performance.

The analysis suggests, first, that the adoption of flexible or managed exchange rates depends on the nature and source of the shocks to the economy. In general, social loss is much higher under managed exchange rates than under flexible exchange rates in the presence of real and foreign shocks, while for nominal shocks the reverse is true. As in the classical work of Poole (1970), the choice of instruments-in this case the choice of exchange rate regimes-is a consequence of uncertainty, thus, the decision will depend on the characteristics of this uncertainty.

Second, the choice of the inflation indicator to be targeted is not independent of the nature of the shock and preferences of the monetary authority (e.g., trade-off between inflation, output,

\footnotetext{
${ }^{2}$ For related literature of closed economy models, see, for instance, King and Wolman (1996), Svensson (1999), and Jadresic (1999). For open economies, see, Ball (1999), Batini and Haldane (1998), Svensson (2000), McCallum and Nelson (1999), and Monacelli (2000).

${ }^{3}$ Currently, some inflation targeters countries target all-items CPI (for example, Germany, Israel, New Zealand, Spain, and Sweden). Some others use the CPI that excludes many volatile prices, such as energy and food prices (Australia, among others). Canada, the United Kingdom, and Chile use both types of measures. In the paper, domestic inflation measures price movements which exclude goods produced in the rest of the world.

${ }^{4}$ Strict inflation targeting is the case in which inflation stabilization is the unique objective of the monetary authority. If the central bank considers not only inflation, but also output and if corresponds exchange rate, this is called flexible inflation targeting.
} 
and the exchange rate). However, in most of the cases domestic inflation targeting is preferable over CPI inflation targeting, because the former better stabilizes not only the two measures of inflation, but also the output gap and the real exchange rate. ${ }^{5}$

Finally, independent of the source of the disturbance, it is always convenient that the monetary authority stabilizes not only inflation, but also output and if it corresponds, the exchange rate. Strict inflation targeting may lead to large output volatility. Flexible inflation targeting allows central banks to maintain stable inflation, while promoting stability in output.

Three sets of issues motivate the investigation. First, since the early 1990s, a substantial number of central banks have implemented what are now called inflation targeting regimes. These regimes have been introduced to reduce inflation or to provide a new nominal anchor for the economy. Countries that have implemented inflation target regimes usually enjoy relative price stability. ${ }^{6}$ However, there are only a few theoretical and less empirical studies that have studied this kind of regime for open economies. Two theoretical exceptions are Ball (1999) and Svensson (2000). Ball concludes that an appropriate policy instrument for open economies is the Monetary Condition Index (MCI), based on both the interest rate and the exchange rate. On the other hand, the Svensson analysis gives restricted support for the MCI and suggests the use of flexible CPI inflation targeting, because it stabilizes inflation, output, and the real exchange rate. This paper develops a simple model which complements the Ball and Svensson analyses. In particular, the model differs from Ball's analysis in including micro-foundations and forward-looking behavior. It also differs from the Svensson's model, in that it isolates the source of the stochastic shocks, and hence, the model can give some policy recommendations depending on the nature and source of the disturbances. Other differences from Svensson are that this paper deals with the formal examination of the effects of different exchange rate regimes, while also considering simple forecast-based monetary policy rules.

Second, although inflation is under reasonable control in the current international environment, monetary and exchange rate policies have not been free of turmoil. Exchange rate management in small open economies has not evolved smoothly. The inability of some central banks to sustain the existing exchange rate system raises the issue of the identity of the better nominal anchor for the economy: the exchange rate or the inflation target. Moreover, the Southeast Asia crisis has raised some questions and provided few formal answers. It has shown that interrelations among countries, through trade and capital markets, can increase the likelihood of a crisis. Thus, domestic monetary and exchange rate policies need to adapt to this new global environment. In that way, it seems to be essential the new

\footnotetext{
${ }^{5}$ Similarly, Jadresic (1999) argues that sticky inflation targeting is preferable, in terms of output stability, to headline CPI inflation targeting. He demonstrates that the result is consistent not only for a closed economy model but also for an open economy setup.

${ }^{6}$ Countries with explicit and mature inflation target regimes include Australia, Canada, Chile, Finland, New Zealand, Spain, Sweden, and the United Kingdom.
} 
discussion about what type of regime should be more suitable for small open economies in terms of economic stability. ${ }^{7}$

Finally, together with the absence of an intermediate target of monetary aggregates or exchange rates, the central bank must also be able to choose independently the targets for effective inflation targeting. In view of this, the paper examines the conditions under which the central bank of an emerging country can effectively implement this kind of regime. In the calibration section of the investigation, the model uses some parameters derived from the case of Chile. It is worth noting that Chile is the only emerging market economy that has followed an inflation targeting regime since the early 1990s and fulfills the general requirements qualifying as a small open economy. ${ }^{8}$ Chilean monetary policy has been well known for its commitment to fighting inflation. During the 1990s, its record in achieving the inflation targets has been outstanding, with an average difference of -0.2 percent (and standard deviation of 1.2 percent) between actual CPI inflation and targets. ${ }^{9}$

The theoretical framework is a dynamic neo-Keynesian model modified to allow for inflation targeting in an open economy. This framework builds on previous research by Svensson (2000), Galí and Monacelli (2002), and Parrado and Velasco (2002), all of which focus on the performance of simple policy rules (whether optimal or not) in open economies. The model contains three structural blocks: aggregate demand, aggregate supply, and a monetary sector. The aggregate demand block is derived from utility maximization. The same is true of aggregate supply, which also incorporates forward-looking sticky prices à la Calvo (1983).

Studying the welfare consequences of monetary rules has only lately become fashionable among academic economists. The issue was not tackled previously for lack of tools rather than lack of interest. The most recent generation of general equilibrium sticky-price models, based on utility maximization, naturally lends itself to welfare analysis, as evidenced by the number of recent papers on the subject. ${ }^{10}$ The model differs from much recent work in two dimensions. First, it focuses on a small open economy, while most papers - with the important exception of Galí and Monacelli (2002) - focus on a world economy composed of two countries of comparable size. As Lane (2001) points out, much of the literature has been based on a two-country world, because this allows interest rates and asset prices to be endogenously determined. However, this benefit comes at the price of considerable model complexity and may not be of compelling importance for the analysis of issues relevant to a

\footnotetext{
${ }^{7}$ The discussion about the effects of exchange rate on economic stability is not new. Fischer (1977) and Flood (1979) present well-known theoretical models that deal with this issue.

${ }^{8}$ See Masson, Savastano, and Sharma (1997).

${ }^{9}$ See Morandé (2001) for a description of the inflation targeting regime in Chile.

${ }^{10}$ A partial list of recent papers incorporating an open economy, aside from works mentioned in the text, includes Benigno and Benigno (2001); Ghironi and Rebucci (2001); and Monacelli (2000).
} 
small open economy. Second, the model focuses on interest rate policies, while most other papers try to characterize the optimal behavior of the nominal quantity of money, starting with the seminal paper by Obstfeld and Rogoff (1995).

The paper is organized as follows. Section II contains a description of the framework and the methodology. Section III presents the solution of the model and its parametrization. Section IV presents the analysis of the experiments. The final section summarizes the results and their implications for models of monetary policy.

\section{The Model ECONOMY}

As mentioned above, this paper utilizes a dynamic neo-Keynesian (DNK) model, modified to allow for inflation targeting in a small open economy. The baseline $\mathrm{DNK}^{11}$ model is essentially a stochastic growth model that includes money, monopolistic competition, and nominal price rigidities.

The model consists of a small open economy in which there is a central bank, a fiscal authority (the government), a representative consumer, and monopolistically competitive firms. All goods are tradable. The representative consumer can hold two types of assets, money and foreign bonds; this individual also supplies labor. As is standard in the literature, production of goods requires a continuum of differentiated labor inputs that are supplied by home individuals. Time is discrete.

Having described the general framework of the model, the analysis proceeds in three stages. The first step outlines the main building blocks of the model and its microeconomic foundations; while the second step derives the main price relationship of the model, namely, inflation rates and exchange rates. Finally, the model embeds these relationships in an otherwise conventional DNK model.

\section{A. Microeconomic Foundations of Demand and Supply}

The economy has a continuum of measure 1 of consumers-producers indexed by $j \in[0,1]$, where each consumer-producer has the same intertemporal lifetime utility function

$$
E_{t}\left[U_{t+k}(j)\right]=E_{t}\left[\sum_{k=0}^{\infty} \beta^{k}\left\{u\left[C_{t+k}(j)\right]+h\left[\frac{M_{t+k}(j)}{P_{t+k}}\right]-\int_{0}^{1} v\left[Y_{t+k}(j) d j\right]\right\}\right],
$$

where $0<\beta<1$ is the discount factor and $C_{t}$ is a composite consumption index defined by

$$
C_{t}=\left[(1-\gamma)^{1 / \eta}\left(C_{H, t}\right)^{(\eta-1) / \eta}+\gamma^{1 / \eta}\left(C_{F, t}\right)^{(\eta-1) / \eta}\right]^{\eta /(\eta-1)},
$$

${ }^{11}$ See Goodfriend and King (1997) for a description of the DNK approach. 
where $\eta>0$ is the elasticity of substitution between domestic and foreign goods and $\gamma$ corresponds to the share of domestic consumption allocated to imported goods. The two consumption subindexes, $C_{H, t}$ and $C_{F, t}$, are symmetric, and they are defined, as in Dixit and Stiglitz (1977), by

$$
C_{H, t}=\left[\int_{0}^{1} C_{H, t}(j)^{(\theta-1) / \theta} d j\right]^{\theta /(\theta-1)} \text { and } C_{F, t}=\left[\int_{0}^{1} C_{F, t}(j)^{(\theta-1) / \theta} d j\right]^{\theta /(\theta-1)}
$$

where $\theta>1$ is the price elasticity of demand faced by each monopolist and $C_{H, t}(j)$ and $C_{F, t}(j)$ are the quantities purchased by home agents of home and foreign goods, respectively.

Consumers can store domestic non-interest-bearing money, and they can also hold statecontingent claims, as in Cole and Obstfeld (1991) and Galí and Monacelli (2002). The latter means that ex-ante international financial markets are complete and thus there is no need for international portfolio diversification. In equilibrium, it also means that transitory shocks do not have permanent consequences, which sharply simplifies the analysis. The individual household constraint is given by

$$
\begin{gathered}
\int_{0}^{1}\left[P_{H, t}(j) C_{H, t}(j)+P_{F, t}(j) C_{F, t}(j)\right]+M_{t}(j)+E_{t}\left[F_{t, t+1} B_{t+1}\right] \\
=(1-\tau) P_{H, t}(j) Y_{H, t}(j)+M_{t-1}(j)+B_{t}(j)+T R_{t},
\end{gathered}
$$

where $F_{t, t+1}$ is the stochastic discount factor, $B_{t+1}$ is the payoff in period $t+1$ of the portfolio held at the end of period $t, T R_{t}$ are lump sum transfers, and $\tau$ is a proportional tax on nominal income.

The home commodity demand functions resulting from cost minimization are

$$
C_{H, t}(j)=\left[\frac{P_{H, t}(j)}{P_{H, t}}\right]^{-\theta} C_{H, t} \quad \text { and } C_{F, t}(j)=\left[\frac{P_{F, t}(j)}{P_{F, t}}\right]^{-\theta} C_{F, t},
$$

where $P_{H, t}$ and $P_{F, t}$ are the price indexes for domestic and foreign goods, both expressed in the domestic currency:

$$
P_{H, t} \equiv\left[\int_{0}^{1} P_{H, t}(j)^{1-\theta} d j\right]^{1 /(1-\theta)} \quad \text { and } P_{F, t} \equiv\left[\int_{0}^{1} P_{F, t}(j)^{1-\theta} d j\right]^{1 /(1-\theta)} \text {. }
$$


Using the definition of total consumption in equation (2), the demand allocation for home and foreign goods is derived:

$$
C_{H, t}=(1-\gamma)\left(\frac{P_{H, t}}{P_{t}}\right)^{-\eta} C_{t} \quad \text { and } C_{F, t}=\gamma\left(\frac{P_{F, t}}{P_{t}}\right)^{-\eta} C_{t} \text {, }
$$

where $P_{t} \equiv\left[(1-\gamma)\left(P_{H, t}\right)^{1-\eta}+\gamma\left(P_{F, t}\right)^{1-\eta}\right]^{1 / 1-\eta}$ is the consumer price index (CPI).

Plugging equation (5) into budget constraint (4), a new expression for the latter in terms of the composite good can be obtained:

$$
P_{t} C_{t}+M_{t}(j)+\mathrm{E}_{t}\left[F_{t, t+1} B_{t+1}\right]=(1-\tau) P_{H, t}(j) Y_{H, t}(j)+B_{t}(j)+M_{t-1}(j)+T R_{t} .
$$

The home agent's problem is to choose paths for consumption, money, and the output of good $j$. Therefore, the representative consumer chooses his optimal holdings of contingent bonds, $B(j)$, and money, $M(j)$, to maximize his expected utility (equation (1)) subject to the budget constraint (equation (6)). It follows that the first-order necessary conditions (FONCs) are

$$
\beta E_{t}\left[\frac{u_{c}\left(C_{t+1}\right)}{u_{c}\left(C_{t}\right)} \frac{P_{t}}{P_{t+1}}\right]=E_{t}\left[F_{t, t+1}\right]
$$

and

$$
u_{c}\left(C_{t}\right)=h_{m}\left(\frac{M_{t}}{P_{t}}\right) \frac{1}{P_{t}}+\beta E_{t}\left[u_{c}\left(C_{t+1}\right) \frac{P_{t}}{P_{t+1}}\right]
$$

Equation (7) represents the traditional intertemporal Euler equation for total real consumption, while equation (8) corresponds to the intertemporal Euler equation for money.

The problem is analogous for the rest of the world, although the crucial assumption here is that the share of goods that are not produced within the economy is insignificant. The Euler equation for the rest of the world would thus be

$$
\beta E_{t}\left[\frac{u_{c}^{*}\left(C_{t+1}\right)}{u_{c}^{*}\left(C_{t}^{*}\right)} \frac{P_{t}^{*}}{P_{t+1}^{*}} \frac{S_{t}}{S_{t+1}}\right]=E_{t}\left[F_{t, t+1}\right]
$$

Combining and iterating equations (7) and (9) yields

$$
u_{c}\left(C_{t}\right)=\kappa u_{c}^{*}\left(C_{t}^{*}\right) Q_{t},
$$


where $Q_{t}=\left(S_{t} P_{t}^{*}\right) / P_{t}$ is the real exchange rate and $\kappa$ is a constant that depends on initial wealth differences. The assumption of complete markets thus leads to equation (10), which associates home consumption with the consumption of the rest of the world and with a switching factor given by the real exchange rate. ${ }^{12}$

The model employs a price-setting process that follows Calvo (1983), in which firms are able to change their prices only with some probability, independently of other firms and the time elapsed since the last adjustment. It is assumed that producers behave as monopolistic competitors. Each firm faces the following demand function:

$$
y_{H, t}^{d}(j)=\left[\frac{p_{H, t}(j)}{P_{H, t}}\right]^{-\theta} C_{H, t}^{A}
$$

where $C_{H, t}^{A}=C_{H, t}+C_{H, t}^{*}$.

Recall that the economy has a continuum of measure 1 of consumer-producers indexed by $j \in(0,1)$, where each consumer-producer has the same expected profit function. It follows that the objective function can be written as

$$
E_{t-1}\left[\sum_{k=0}^{\infty} \alpha^{k} \beta^{k} \Lambda_{t+j}\left\{\frac{p_{H, t}(j)}{P_{H, t+k}}\left[\frac{p_{H, t}(j)}{P_{H, t+k}}\right]^{-\theta} C_{H, t+k}^{A}-\frac{W_{t+k}}{P_{H, t+k}} \frac{V\left[p_{H, t}(j) / P_{H, t+k}\right]^{-\theta} C_{H, t+k}^{A}}{\widetilde{Z}_{t+k}}\right\}\right]
$$

where $\alpha$ is the probability that consumer-producers maintain the same price of the previous period, $\Lambda_{t+j}$ is the marginal utility of home goods, $V\left(y_{H, t}^{d}\right) / \widetilde{Z}_{t}$ is the input requirement function, $\widetilde{Z}_{t}$ is an exogenous economy-wide productivity parameter, and $W_{t}$ is the price of the composite input.

The problem of the producers, which is solved in Appendix I, is to choose $p_{H, t}(j)$ to maximize equation (12) subject to equation (11).

\footnotetext{
${ }^{12}$ The assumption of complete markets has the additional advantage of eliminating foreign asset movements from the dynamics of the economy. As a result, the steady state is unique, in that consumption is independent of the past history of shocks. Thus, the model can be linearized around that unique steady state. This is not possible in standard models of small open economies.
} 


\section{B. Government}

The model assumes that the government balances its budget each period. The government budget constraint is thus given by

$$
\tau P_{H, t} Y_{H, t}-T R_{t}+M_{t}-M_{t-1}=0 .
$$

The analysis is restricted to the case in which $\tau=1 /(1-\theta)$. In this case, the government offsets the market power distortion created by monopolistic competition in the market for differentiated goods. This means that the only distortion in the economy is price rigidity, and offsetting the effects of that distortion is the object of monetary policy.

\section{Price Relationships}

Before moving on to the complete log-linearized model, the price relationships involved in the model are defined in $\log$ terms. Let $p_{H, t}$ and $p_{F, t}$ be the stochastic components of $(\log )$ levels of domestic and foreign good prices, respectively, in period $t$. Thus the (log) consumer price index $(\mathrm{CPI})$ can be defined as

$$
p_{t}=(1-\gamma) p_{H, t}+\gamma p_{F, t},
$$

where $\gamma$, a parameter of the utility function, is the share of home goods in the CPI, with $0<\gamma<1$. Therefore, the $(\log )$ CPI inflation can also be defined as

$$
\pi_{t}=(1-\gamma) \pi_{H, t}+\gamma \pi_{F, t},
$$

where $\pi_{H, t}=p_{H, t}-p_{H, t-1} \quad$ is domestic inflation and $\pi_{F, t}=p_{F, t}-p_{F, t-1}$ denotes foreign inflation. Depending on the choice of the inflation target (CPI versus domestic inflation), $\pi_{t}$ and $\pi_{H, t}$ will be measured as deviations from a constant mean, which equals the constant inflation target.

The $(\log )$ real exchange rate can similarly be defined as

$$
q_{t} \equiv s_{t}+p_{t}^{*}-p_{t} \Rightarrow q_{t}=(1-\gamma)\left(s_{t}+p_{t}^{*}-p_{H, t}\right)
$$

where $s_{t}$ represents the $(\log )$ nominal exchange rate and where it has included the key assumption that the rest of the world behaves as a closed economy, that is, $p_{t}^{*}=p_{F, t}^{*}$. In other words, it is assumed that the rest of the world's consumption of foreign goods (that is, of the goods produced by the home economy) is negligible. ${ }^{13}$

${ }^{13}$ Galí and Monacelli (2002) use the same approximation. 


\section{The Log-Linearized Model}

This section presents the complete log-linearized model of this open economy. Additional details are presented in Appendix I. Lowercase variables denote percent deviations from the steady state, and ratios of capital letters without time subscript denote steady-state values of the respective ratios. The complete log-linearized model is expressed in terms of three blocks of equations: aggregate demand, aggregate supply, and monetary policy rules and stochastic processes.

\section{Aggregate Demand}

Aggregate demand in this economy is given by

$$
x_{t}=E_{t}\left[x_{t+1}\right]+\phi_{\pi} E_{t}\left[\pi_{H, t+1}\right]-\phi_{s}\left(E_{t}\left[s_{t+1}\right]-s_{t}\right)-\frac{1}{\sigma} i_{t}-\left(1-\rho_{z}\right) z_{t}+\gamma\left(1-\rho_{y^{*}}\right) y_{t}^{*},
$$

where $\phi_{\pi}=[(1-\gamma) / \sigma+\gamma \eta(2-\gamma)], \phi_{s}=\gamma[\eta(2-\gamma)-1 / \sigma], 0 \leq \rho_{z} \leq 1$, and $0 \leq \rho_{y^{*}} \leq 1$.

Note that $\left.i_{t}=\left(P_{t+1} / P_{t}\right) E_{t} \mid F_{t, t+1}\right\rfloor$ is the nominal interest rate, while $y_{t}^{*}=c_{t}^{*}$ is foreign output, which follows a stationary univariate $\mathrm{AR}(1)$ process.

Equation (16) represents a nontraditional IS curve that relates the output gap not only to the interest rate, but also to the expected future output gap and current and expected future nominal exchange rates. A nominal depreciation, and consequently a real depreciation, raises aggregate demand, because it shifts demand from foreign goods to domestic output (foreign prices are given, and any repercussion effects from the home economy to the rest of the world are neglected).

\section{Aggregate Supply}

Aggregate supply is obtained by log-linearizing the first-order condition of the price setting problem. It follows that

$$
\pi_{H, t}=\beta E_{t}\left[\pi_{H, t+1}\right]+\lambda_{x} x_{t}+\lambda_{q}\left(s_{t}+p_{t}^{*}-p_{H, t}\right),
$$

and

$$
\pi_{t}=\gamma \pi_{H, t}+(1-\gamma)\left(s_{t}-s_{t-1}\right)
$$

where $\lambda_{x}=\{[(1-\alpha)(1-\alpha \beta)] / \alpha(1+\varepsilon \theta)\} \xi, \lambda_{q}=\lambda_{x} \gamma$, and $z_{t}$ is an economy-wide productivity shock.

Equation (17) embeds the staggered price setting formulation of Calvo (1983) described earlier, giving rise to the dynamic version of the aggregate supply schedule for domestic goods. Current domestic inflation depends on expected future domestic inflation, current 
domestic output, and the terms of trade. This reflects the forward-looking nature of price setting, stemming from the implicit costs of changing prices.

Equation (18) defines CPI inflation in terms of domestic inflation and accumulated nominal exchange rate depreciation. Derivation of this equation assumes that foreign prices are constant.

\section{Uncovered Interest Parity Condition}

The uncovered interest parity condition is given by

$$
i_{t}=i_{t}^{*}+E_{t}\left[s_{t+1}\right]-s_{t}
$$

which relates the movements of the interest rate differentials to the expected variations in the nominal exchange rate.

\section{Monetary Policy Rules and Stochastic Processes}

It is assumed that the central bank manages a short-term nominal interest rate according to an open economy variant of the Taylor rule. Specifically, the model considers a rule in which the central bank adjusts the current nominal interest rate in response to expected inflation, the current output gap, the current exchange rate, and the lagged interest rate. In general, this kind of rule describes the variation of short-term interest rates relatively well. ${ }^{14}$

As Clarida, Galí, and Gertler (1998) suggest, the current interest rate depends on the interest rate target and lagged interest rate, i.e., there is a degree of interest rate smoothing, given by $\rho_{i}$. The assumption behind this point is that monetary authorities are concerned about interests rate volatility, because it is costly in terms of market information, and consequently investment and growth. Thus,

$$
i_{t}=\left(1-\rho_{i}\right) \overline{i_{t}}+\rho_{i} i_{t-1},
$$

where $\bar{i}_{t}$ is the nominal interest target toward which the central bank gradually adjusts the interest rate, given by

$$
\bar{i}_{t}=\chi_{\pi} E_{t}\left[\tilde{\pi}_{t+k}-\bar{\pi}\right]+\chi_{x} x_{t}+\chi_{s} s_{t}
$$

where $\chi_{\pi}>1, \chi_{x} \geq 0$, and $\chi_{s} \geq 0$ and where $\pi_{t, k}=\tilde{\pi}_{t+k}-\bar{\pi}, \tilde{\pi}_{t+k}$ denotes the percent change in the price level between periods $t$ and $t+k$, and $\bar{\pi}$ is the inflation target. ${ }^{15}$ It is important to

${ }^{14}$ See Clarida, Galí, and Gertler (1998 and 2000) and Rotemberg and Woodford (1998b).

15 The assumption is that the inflation target is constant and equal to 0 . Since the target is constant, there are no changes if this is greater than zero. However, as Bernanke, Laubach, 
note that the policy rule used by the monetary authority depends on expected future inflation. Higher than expected future inflation raises current nominal interest rate target. Batini and Haldane (1998) also consider this kind of policy rule. They conclude that inflation forecastbased policy rules embody all information useful for predicting future inflation, and can achieve a high degree of output smoothing.

Including the term $\chi_{s}$ in the policy rule helps to reproduce the behavior of nominal exchange rates. Depending on the degree of control that the central bank exercises over the nominal exchange rate - the value of $\chi_{s}$-it will imply the type of regime that the country has chosen. In other words, if $\chi_{s}=0$, it means that the central bank does not care about deviations of the nominal exchange rate, i.e., the economy has a flexible exchange rate. On the other hand, if $\chi_{s}>0$, it means that the central bank acts if there is some deviation of the nominal exchange rate of its current target or steady state value. Thus, this case corresponds to a managed exchange rate, and in the extreme to a fixed exchange rate.

Therefore, plugging equation (21) into equation (20), the monetary policy rule is given by ${ }^{16}$

$$
i_{t}=\rho_{i} i_{t-1}+v_{\pi} E_{t}\left[\pi_{t+k}\right]+v_{x} x_{t}+v_{s} s_{t}+\epsilon_{t},
$$

Mishkin, and Posen (1999) pointed out, the policy recommendation should consider a rate above 0 , because price indices may be biased upward. The main reasons are: first, price indices consider fixed weights, and hence they do not take into account the possibility of substitution in consumption from goods whose prices are rising to substitutes goods with lower prices. Second, the price indices, in general, do not adjust for new goods or improvement in quality. Thus, higher prices-due to higher quality-should not be counted as inflation. There are also well-known economic reasons, such as rigid downward nominal wages and low level of nominal interest rates.

${ }^{16}$ An important consideration is in order about the definition of inflation targeting. Some authors argue, as in McCallum and Nelson (1999) and Batini and Haldane (1998), that inflation targeting is the case in which the monetary policy instrument responds to alternative variables, such as inflation, output, and exchange rates. Other authors led by Lars Svensson stress that targeting one or several variables means minimizing a loss function that is increasing in the deviation between the target variable(s) and the target level(s). He pointed out, that "the best way to minimize such a loss function is then to respond optimally with the instrument to the determinants of the target variables, that is, the state variables of the economy." Therefore, these two definitions would be similar only if there were a one to one relation between the variables in the reaction function and the loss function. Leitemo (1999) suggests that there are advantages in committing to a specific interest rate rule instead of letting the monetary authority discretionarily decide on the inflation targeting policy. The present paper examines equilibria resulting from commitment to alternative instrument rules. 
where $v_{\pi}=\left(1-\rho_{i}\right) \chi_{\pi}, v_{x}=\left(1-\rho_{i}\right) \chi_{x}, v_{s}=\left(1-\rho_{i}\right) \chi_{s}$, and $\in_{t}$ is an interest rate shock. This shock has two interpretations: it may capture deliberate decisions to deviate temporarily from its systematic rule, and/or erratic monetary policy if there is, for example, another monetary policy instrument.

Finally, equations (23), (24), (25), and (26) describe the evolution of foreign interest rate, foreign output, productivity, and domestic interest rate shocks respectively.

$$
\begin{aligned}
& r_{t}^{*}=\rho_{r^{*}} r_{t-1}^{*}+\varepsilon_{t}^{r^{*}}, \\
& y_{t}^{*}=\rho_{y^{*}} y_{t-1}^{*}+\varepsilon_{t}^{y^{*}}, \\
& z_{t}=\rho_{z} z_{t-1}+\varepsilon_{t}^{z}, \\
& \epsilon_{t}=\rho_{\epsilon} \in_{t-1}+\varepsilon_{t}^{\epsilon} .
\end{aligned}
$$

where $\varepsilon_{t}^{r^{*}}, \varepsilon_{t}^{y^{*}}, \varepsilon_{t}^{z}$, and $\varepsilon_{t}^{\epsilon}$ are independent and identically distributed (i.i.d.) shocks with zero mean and variance $\sigma_{r^{*}}^{2}=0.25, \sigma_{y^{*}}^{2}=1, \sigma_{z}^{2}=1$, and $\sigma_{\epsilon}^{2}=0.25$.

\section{E. Welfare Criterion}

To evaluate the welfare implications of alternative monetary policy rules and exchange rate regimes a welfare criterion is needed. This welfare criterion is based on expected social loss. Social loss is, in turn, assumed to depend on the deviations of output and inflation from their steady-state values, and possibly on other variables. The assumptions on social loss may be seen as an approximation of some aggregate of the welfare of consumer-producers.

Therefore, the welfare criterion of the home country, disregarding liquidity effects, is defined broadly as ${ }^{17}$

$$
L_{t}=\psi_{\pi} \pi_{H, t}^{2}+\psi_{x} x_{t}^{2}+\psi_{q} q_{t}^{2} .
$$

After taking unconditional expectations, the loss function becomes

$$
E\left[L_{t}\right]=\psi_{\pi} \operatorname{Var}\left[\pi_{H, t}\right]+\psi_{x} \operatorname{Var}\left[x_{t}\right]+\psi_{q} \operatorname{Var}\left[q_{t}\right]
$$

${ }^{17}$ The instrument of the monetary authority is the short nominal interest rate. This implies that the behavior of monetary aggregates plays no essential role in the analysis. 
where $\operatorname{Var}\left[\pi_{H, t}\right], \operatorname{Var}\left[x_{t}\right]$, and $\operatorname{Var}\left[q_{t}\right]$ are the unconditional variances of domestic inflation, the output gap, and the real exchange rate, respectively.

The fact that the loss function considers domestic inflation can be justified in the context of the Calvo (1983) staggered setup. As Woodford (1996, 1999, 2001), Rotemberg and Woodford (1998a, 1998b), and Benigno (2000) show in detail, staggering inflation causes the dispersion of relative prices, which is costly for output and welfare. Since domestic prices are sticky in the model, ongoing domestic inflation causes such relative price distortions.

Designing the optimal monetary policy involves minimizing equation (27). ${ }^{18}$ The strategy of this paper is to compare alternative (nonoptimal) policy rules using this benchmark criterion. It is assumed that the welfare criterion for the small open economy includes not only variations in output and inflation, as is standard in the closed economy case, but also changes in the real exchange rate. In particular, the paper analyzes the broad case in which the loss function considers the following weights: $\psi_{\pi}=1.5 ; \psi_{x}=0.5$; and $\psi_{q}=0.5$.

To make sure that the results do not depend on the particular specification of the loss function, with different weights for inflation, output gap, and the real exchange rate were considered. In general, the main conclusions do not differ with alternative reasonable parameter values.

\section{Model Simulations}

This section describes the results of some quantitative experiments indicating how inflation targeting can influence business cycle dynamics within the DNK framework. Specifically, the paper considers three types of exercises. First, the model compares flexible versus managed exchange rates, considering both CPI and domestic inflation targeting. Second, the model studies how the choice between CPI inflation and domestic inflation targets influences the behavior of output, inflation, interest and exchange rates. Finally, the analysis contrasts differences between strict and flexible inflation targeting.

\section{A. Model Parametrization}

For parameter values, standard values that appear in the traditional related literature are chosen, which are in order of magnitude with Chilean estimations (forecast-based policy rule). The first subsection presents estimates of the Central Bank of Chile's feedback rule found in Parrado (2000), while the second subsection considers the choice of parameter values from the traditional literature.

${ }^{18}$ See Svensson (2000) for a detailed derivation of an optimal reaction function under the Calvo (1983) scheme. See also Parrado and Velasco (2002) for solution methods similar to those based on Obstfeld and Rogoff (1995). 


\section{Monetary Policy Rule}

Empirical research suggests that many countries have used anticipated future inflation rather than current or lagged inflation. Parrado (2000) employs generalized method of moments (GMM) to show that the Central Bank of Chile's actions during the 1990s were driven mainly by an inflation-forecast-based policy rule. Table 1 reports GMM estimates of coefficients $\chi_{\pi}, \chi_{x}, \chi_{s}$, and $\rho_{i}$ using monthly time series from 1990:12 to 1999:02. These estimates yield several results. First, the coefficient associated with expected inflation is greater than one; this indicates that whenever expected inflation rose, the Central Bank of Chile reacted by increasing real interest rates aggressively. Second, the coefficient that captures interest inertia is low $\left(\rho_{i} \cong 0.5\right)$, which suggests that the monetary authority reacted, to some extent, independently of the level of past interest rates. Third, the coefficient associated with output does not have the expected sign, but it is not significant. ${ }^{19}$ Therefore, the hypothesis that $\chi_{x}$ is 0 cannot be rejected. Finally, estimates of $\chi_{s}$ (the coefficient that measures the sensitivity to the exchange rate) are high and significant. This indicates that the Central Bank of Chile was trying to stabilize exchange rates during the 1990s.

Table 1. GMM Estimations of the Central Bank of Chile's Reaction Function ${ }^{\mathrm{a}}$

\begin{tabular}{cccccc}
\hline $\begin{array}{c}\text { Reaction to } \\
\text { inflation }\end{array}$ & $\chi_{\pi}$ & $\chi_{x}$ & $\chi_{s}$ & $\rho$ & $p$-value \\
\hline Expected inflation & 1.98 & -0.18 & 3.34 & 0.50 & 0.06 \\
(6 periods ahead) & $(0.61)$ & $(2.16)$ & $(1.92)$ & $(0.15)$ & \\
\hline Expected inflation & 2.03 & -0.22 & 3.33 & 0.50 & 0.06 \\
(3 periods ahead) & $(0.63)$ & $(1.97)$ & $(1.90)$ & $(0.15)$ & \\
\hline Current inflation & 3.50 & 3.01 & 1.45 & 0.73 & 0.07 \\
& $(2.77)$ & $(5.02)$ & $(4.06)$ & $(0.18)$ & \\
\hline
\end{tabular}

a. The set of instruments includes one to six, nine, and twelve lags of inflation, output, the interest rate, commodity price inflation, and money growth. Standard deviations are in parentheses.

In sum, from the estimations it is possible to deduce that the Central Bank of Chile tried to stabilize only inflation (ignoring output stabilization), directly through the inflation target and indirectly through the nominal exchange rate and the current account. ${ }^{20}$

\section{Other Parameter Values}

The following parameter values are selected both from traditional related literature and from current Chilean data. The quarterly discount factor is set at $\beta=0.99$. The share of domestic goods in total home consumption is assumed to be $\gamma=0.29$, which is equivalent to the average share of Chilean imports in its GDP over the period 1998-2000. The probability that

${ }^{19}$ It is worth noting that the official mandate of the Central Bank of Chile considers two main objectives: inflation stability and current account stability.

${ }^{20}$ The estimates in Parrado (2000) do not differ significantly between CPI and domestic inflation. 
a firm does not change its price within a given period, $\alpha$, is set equal 0.75 , which implies that the frequency of price adjustment is four quarters. The price demand elasticity or the degree of monopolistic competition, $\theta$, is set at 4.33. It is assumed that $\sigma=1$, which corresponds to $\log$ utility, and it is also assumed that the elasticity of substitution between domestic and foreign goods, $\eta$, equals 1.5 .

In the policy rule (equation (22)), the degree of interest rate smoothing, $\rho_{i}$, is equal to 0.7 and the coefficient of inflation, $\chi_{\pi}$, is 1.5 . The simulations compare rules with $\chi_{x}=0.5$ against $\chi_{x}=0.0$ and rules with $\chi_{s}=0$ against $\chi_{s}=3.34$.

Finally, the serial correlation parameters for foreign interest rate, foreign output, productivity, and domestic interest rate shocks, $\rho_{r^{*}}, \rho_{y^{*}}, \rho_{z}$, and $\rho_{\epsilon}$, respectively, are set equal to 0.8 .

\section{B. Model Solution}

The dynamic system is given by equations (16), (17), (19), and (22) and by the definition of domestic inflation, $\pi_{H, t}=p_{H, t}-p_{H, t-1}$. In matrix form, the system is the following:

$$
E_{t}\left[\mathbf{k}_{t+1}\right]=\mathbf{A} \mathbf{k}_{t}+\mathbf{B} \mathbf{v}_{t},
$$

where $\mathbf{k}_{\mathbf{t}}$ is a vector of endogenous variables, $\mathbf{k}_{t}=\left(y_{t}, \pi_{H, t}, s_{t}, i_{t-1}, p_{H, t-1}\right)^{\prime}, \mathbf{A}$ is a five-by-five matrix of coefficients, $\mathbf{B}$ is a five-by-four matrix of coefficients, and $\mathbf{v}_{t}=\left(r_{t}^{*}, y_{t}^{*}, z_{t}, \in_{t}\right)^{\prime}$. The dynamic system has two predetermined variables, $i_{t-1}$ and $p_{H, t-1}$, and three nonpredetermined variables, $y_{t}, \pi_{H, t}$, and $s_{t}$. As shown in Blanchard and Kahn (1980), if the number of eigenvalues of $\mathbf{A}$ outside the unit circle is equal to the number of nonpredetermined variables - in this case three - then there exists a unique rational expectations solution to system (28).

The strategy is to transform the model into canonical form. Let $\mathbf{A}=\mathbf{Q} \mathbf{J} \mathbf{Q}^{-1}$, where $\mathbf{J}$ is the Jordan matrix associated with $\mathbf{A}$, and $\mathbf{Q}$ is the corresponding matrix of eigenvectors. It is possible to define the vector of canonical variables as $\mathbf{w}_{t}=\mathbf{Q}^{-1} \mathbf{k}=\left(a_{t}, b_{t}\right)$, where $a_{t}$ and $b_{t}$ are associated with the unstable and stable eigenvalues, respectively. Let $\mathbf{J}$ and $\mathbf{Q}$ be the corresponding partition of the Jordan matrix and matrix of eigenvectors, respectively, with

$$
\mathbf{J}=\left[\begin{array}{cc}
J_{a} & 0 \\
0 & J_{b}
\end{array}\right] \text { and } \mathbf{Q}=\left(Q_{a}, Q_{b}\right)
$$

Thus, system (28) can be rewritten as

$$
E_{t}\left[\begin{array}{l}
a_{t+1} \\
b_{t+1}
\end{array}\right]=\left[\begin{array}{cc}
J_{a} & 0 \\
0 & J_{b}
\end{array}\right]\left[\begin{array}{l}
a_{t} \\
b_{t}
\end{array}\right] .
$$


The canonical system requires to set $a_{t}=0, \forall t$, to rule out explosive solutions. If the number of eigenvalues outside the unit circle is equal to the number of nonpredetermined variables, the appropriate normalization choice is

$$
b_{t}=\left[\begin{array}{c}
i_{t-1} \\
p_{H, t-1}
\end{array}\right] \text {. }
$$

It is known that $i_{t-1}$ and $p_{H, t-1}$ are predetermined, and therefore $b_{t+1}=E_{t}\left[b_{t+1}\right]$. This implies that $b_{t}=\varphi_{\mathrm{b}} b_{t+1}$, where $\varphi_{\mathrm{b}}$ is a two-by-two matrix with the two stable eigenvalues in the diagonal. This type of equilibrium implies that output, inflation, the real exchange rate, and the interest rate converge monotonically toward their steady states.

\section{RESUlTS AND COMPARISONS}

Four types of aggregate shocks are considered: foreign interest rate shocks, foreign output shocks, technology shocks, and domestic interest rate shocks. Each shock is a first-order process, as described above. As Rotemberg and Woodford (1998a) stress, one has to present unconditional standard deviations to obtain a policy evaluation criterion that is not subject to any problem of time consistency. In other words, the analysis does not impose any condition on the current state of the economy at the particular date at which the policy action is to be taken. Selected unconditional standard deviations for each shock are reported in Appendix II for all exercises.

The foreign interest rate shock has effects on both regions: the open economy and the rest of the world. Therefore, whenever an unanticipated increase of 25 basis points in the foreign nominal interest rate is experienced, a negative shock in foreign output with variance 3.76 is included. $^{21}$

Finally, each subsection presents the impulse-response functions of key variables to different stochastic disturbances for different exchange rate regimes and inflation targeting regimes.

\section{A. Flexible Versus Managed Exchange Rates}

Figures 1 and 2 display the responses of the small open economy to different types of shocks under two different scenarios: a floating exchange rate regime and a managed exchange rate regime. In addition, Figure 1 presents the impulse response functions in the presence of domestic inflation targeting, whereas Figure 2 takes into consideration CPI inflation targeting.

${ }^{21}$ To obtain the variance of the rest of the world's variables, the dynamic behavior of the rest of the world is computed assuming that the consumption of domestic goods is negligible. It is also assumed that the foreign monetary authority follows a traditional Taylor rule with parameters $\chi_{\pi^{*}}=1.5$ and $\chi_{y^{*}}=0.5$. 
Figure 1: Flexible vs. Managed Exchange Rate: Domestic Inflation Targeting
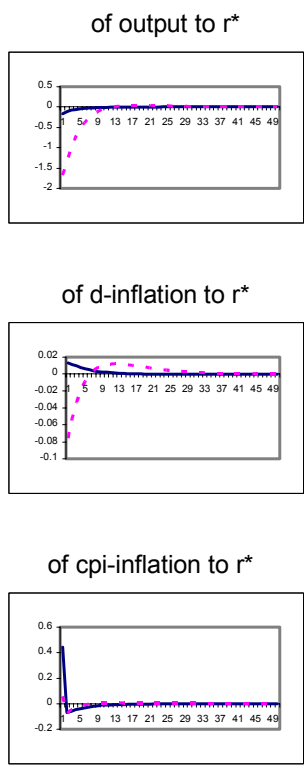

of nom. exc. rate to $r^{*}$

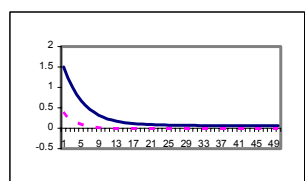

of real ex. rate to $r^{*}$

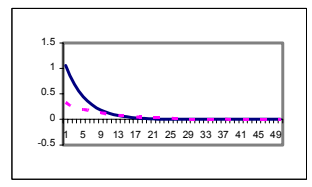

of nom. int. rate to $r^{*}$
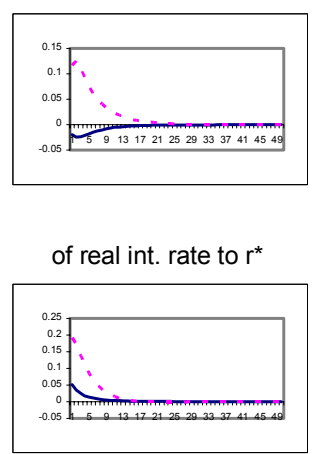

of output to $\mathrm{y}^{*}$

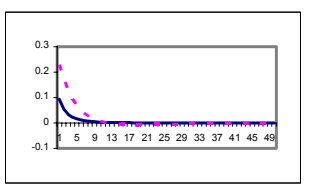

of d-inflation to $\mathrm{y}^{*}$

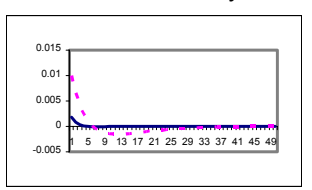

of cpi-inflation to $\mathrm{y}^{*}$

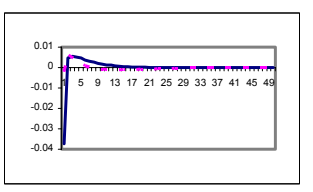

of nom. exc. rate to $y^{*}$

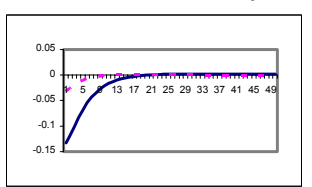

of real ex. rate to $y^{*}$

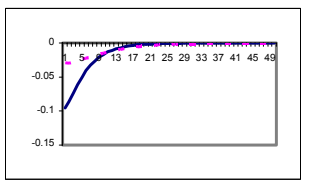

of nom. int. rate to $y^{*}$

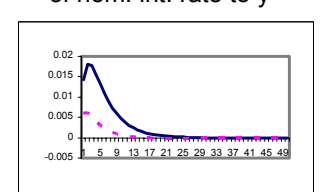

of real int. rate to $\mathrm{y}^{*}$

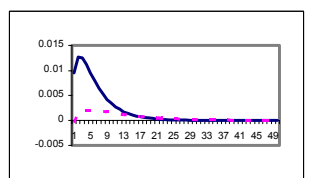

of output to $z$

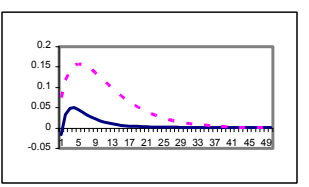

of d-inflation to $z$

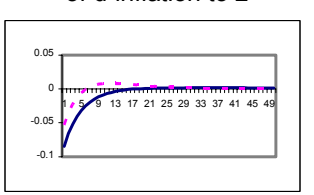

of cpi-inflation to z

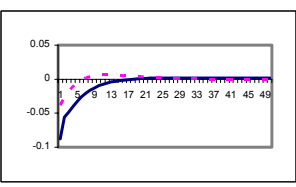

of nom. exc. rate to $z$

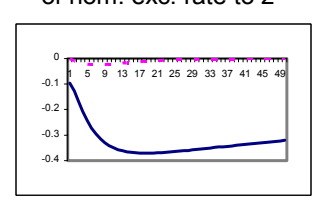

of real ex. rate to $z$

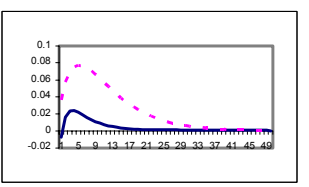

of nom. int. rate to $z$

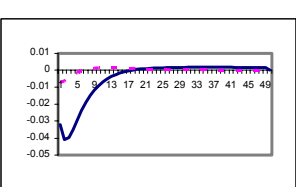

of real int. rate to $z$

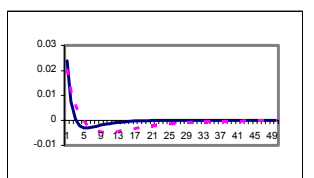

of output to $\mathrm{i}$

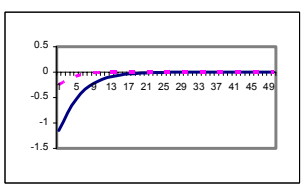

of d-inflation to i

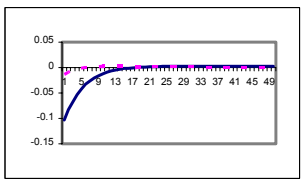

of cpi-inflation to i

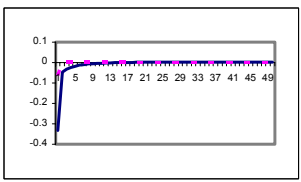

of nom. exc. rate to $\mathrm{i}$

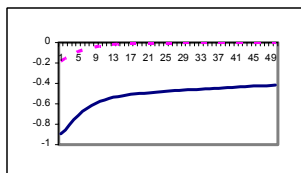

of real ex. rate to $i$

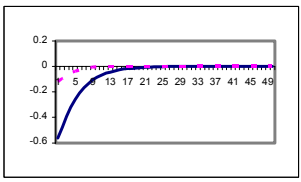

of nom. int. rate to $\mathrm{i}$

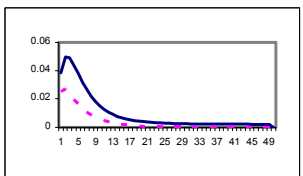

of real int. rate to $\mathrm{i}$

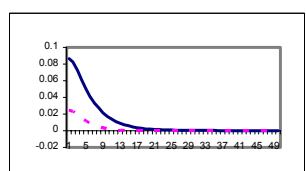

Note: The first column presents impulse-response functions to a $25 \mathrm{bps}$. Temporary innovations in the foreign interest rate; the second to a 1 percent foreign output shock; the third to a 1 percent total factor productivity shock; and the fourth to a 25 bps. temporary innovations in the domestic interest rate. The solid line corresponds to a flexible exchange rate and the dashed line to a managed exchange rate. 


\section{Figure 2: Flexible vs. Managed Exchange Rate: CPI Inflation Targeting}

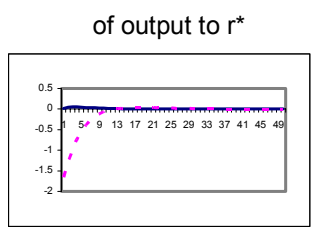

of d-inflation to $r^{*}$

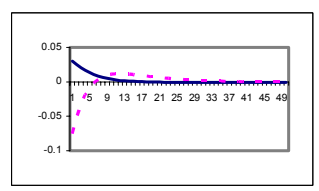

of cpi-inflation to $r^{*}$

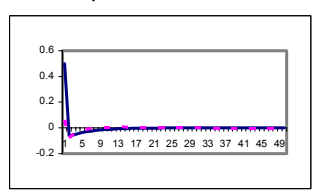

of nom. exc. rate to $r^{*}$

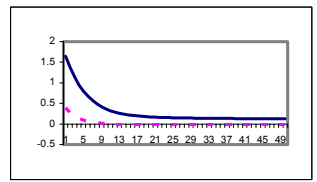

of real ex. rate to $r^{*}$

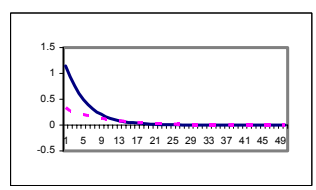

of nom. int. rate to $r^{*}$

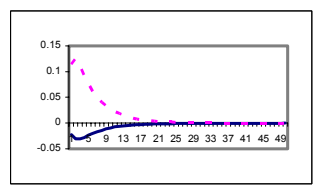

of real int. rate to $r^{*}$

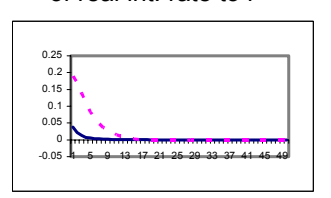

of output to $\mathrm{y}^{*}$

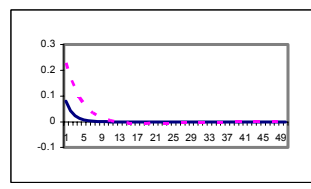

of d-inflation to $\mathrm{y}^{*}$

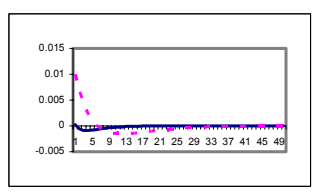

of cpi-inflation to $\mathrm{y}^{*}$

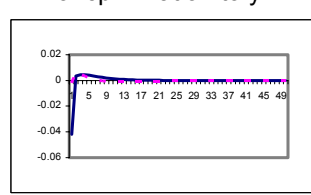

of nom. exc. rate to $y^{*}$

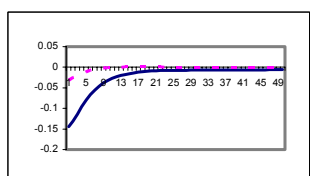

of real ex. rate to $\mathrm{y}^{*}$

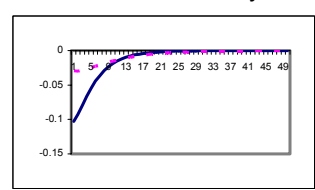

of nom. int. rate to $\mathrm{y}^{*}$

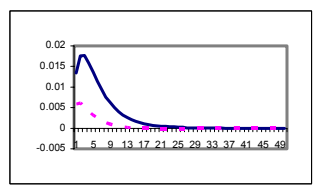

of real int. rate to $\mathrm{y}^{*}$

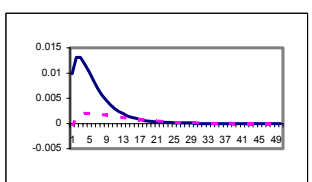

of output to $z$

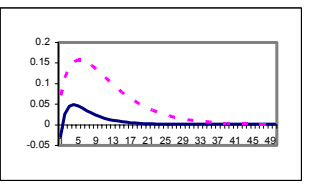

of d-inflation to $z$

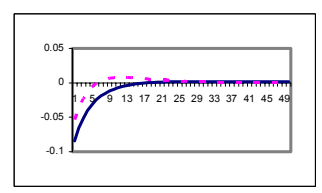

of cpi-inflation to $z$

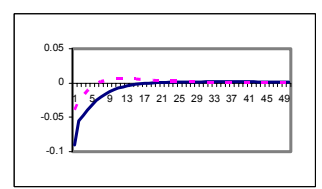

of nom. exc. rate to $z$

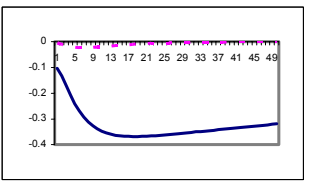

of real ex. rate to $z$

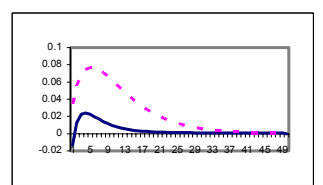

of nom. int. rate to $z$

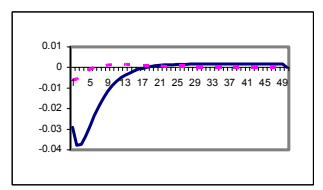

of real int. rate to $z$

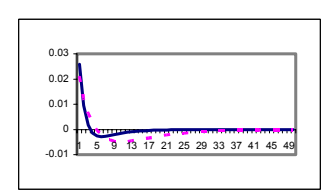

of output to $i$

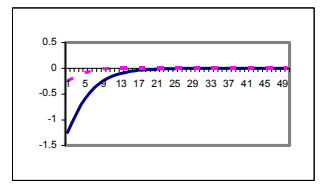

of d-inflation to i

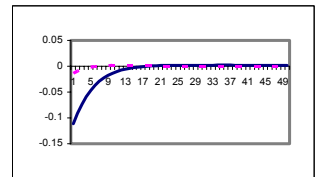

of cpi-inflation to i

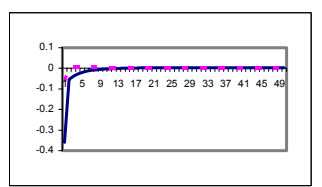

of nom. exc. rate to $\mathrm{i}$

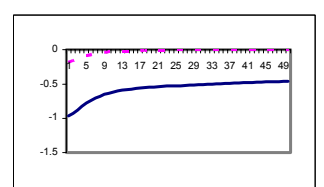

of real ex. rate to $\mathrm{i}$

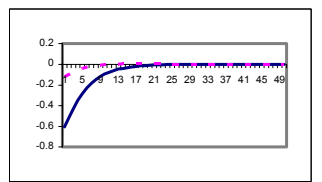

of nom. int. rate to $i$

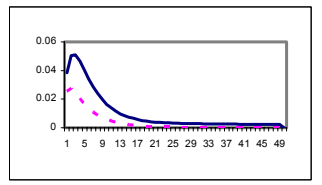

of real int. rate to $i$

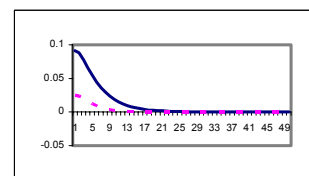

Note: The first column presents impulse-response functions to a 25 bps. Temporary innovations in the foreign interest rate; the second to a 1 percent foreign output shock; the third to a 1 percent total factor productivity shock; and the fourth to a 25 bps. temporary innovations in the domestic interest rate. The solid line corresponds to a flexible exchange rate and the dashed line to a managed exchange rate. 
Recall that under the managed exchange rate, the monetary authority gives some weight to exchange rate stabilization in its policy rule, that is, $\chi_{s} \in(0, \infty)$. Since an inflation targeting regime does not allow for a pure fixed exchange rate, the policy instrument is still the nominal interest rate. In the flexible exchange rate case, the central bank adopts a feedback rule that adjusts the nominal rate to variations in output and inflation only, that is, $\chi_{s}=0$.

To demonstrate the dynamic properties of the model, the example of a foreign disturbance that hits the economy is used. The results are consistent with previous studies and conventional wisdom. Under managed exchange rates, the domestic interest rate rises to match the foreign rate movement, at least partially. Nominal rigidities further cause a significant rise in the real interest rate, which, in turn, induces a contraction in output.

Under flexible exchange rates, the domestic nominal interest rate is no longer tied to the foreign interest rate. The foreign interest rate shock thus produces a considerable nominal depreciation, which has a significant impact on CPI inflation. Output volatility is lower in the flexible case than in the managed case because adjustment is immediately reached through changes in the nominal exchange rate and not through changes in the price level. CPI inflation also differs across exchange rate regimes. If this economy has pegged exchange rates, inflation volatility is consistently lower than in an economy with flexible exchange rates.

\section{Welfare Comparisons}

Table 2 compares the welfare loss associated with alternative monetary policies and different unanticipated innovations. The main result is that flexible exchange rates dominate managed exchange rates if the economy is hit by foreign interest, foreign output, and productivity innovations, while the reverse is true for nominal interest rate shocks. This confirms the conventional wisdom that flexibility is better in the case of foreign and real shocks, while pegging is preferable in the case of nominal shocks.

Table 2. Welfare Loss

\begin{tabular}{lcccc}
\hline & \multicolumn{4}{c}{ Type of shock } \\
\cline { 2 - 5 } Targeting case & $\begin{array}{c}\text { Foreign } \\
\text { interest rate } \\
\left(r_{t}^{*}\right)\end{array}$ & $\begin{array}{c}\text { Foreign } \\
\text { output } \\
\left(y_{t}^{*}\right)\end{array}$ & $\begin{array}{c}\text { Technology } \\
\left(z_{t}\right)\end{array}$ & $\begin{array}{c}\text { Nominal } \\
\text { interest rate } \\
\left(\in_{t}\right)\end{array}$ \\
\hline $\begin{array}{l}\text { Flexible CPI inflation targeting } \\
\text { Flexible exchange rate }\end{array}$ & 1.8722 & 0.0229 & 0.0347 & 2.9785 \\
$\quad$ Managed exchange rate & 3.4804 & 0.0601 & 0.1578 & 0.0920 \\
\hline Strict CPI inflation targeting & & & & \\
$\quad$ Flexible exchange rate & 2.9837 & 0.0642 & 0.0964 & 96.6302 \\
$\quad$ Managed exchange rate & 4.5803 & 0.0800 & 0.1857 & 0.1263 \\
\hline Flexible domestic inflation targeting & 1.5876 & 0.0229 & 0.0345 & 2.5242 \\
$\quad$ Flexible exchange rate & 3.5089 & 0.0602 & 0.1581 & 0.0884 \\
$\quad$ Managed exchange rate & 1.4537 & 0.0745 & 0.0718 & 45.5737 \\
\hline Strict domestic inflation targeting & & 0.0796 & 0.1861 & 0.1203 \\
$\quad$ Flexible exchange rate & 4.5890 & & & \\
$\quad$ Managed exchange rate & & &
\end{tabular}




\section{B. CPI Versus Domestic Inflation Targeting}

Figures 3 and 4 present impulse response functions comparing CPI and domestic inflation targeting. Figure 3 considers the responses in the presence of flexible exchange rates, while Figure 4 covers the managed exchange rate case.

Figure 3: CPI vs. Domestic Inflation Targeting: Flexible Exchange Rate

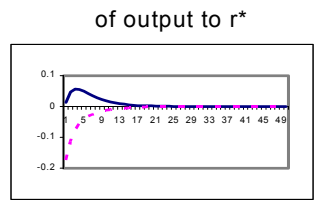

of d-inflation to $r^{*}$

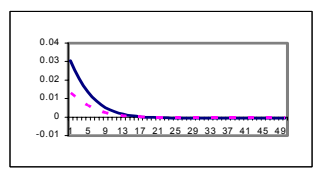

of cpi-inflation to $r^{*}$

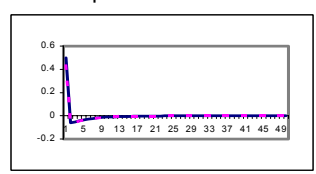

of nom. exc. rate to $r^{*}$

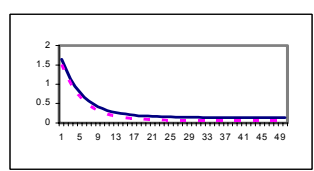

of real ex. rate to $r^{*}$

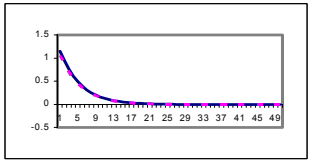

of nom. int. rate to $r^{*}$

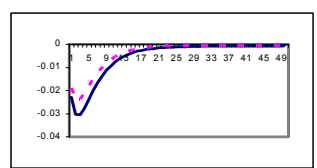

of real int. rate to $r^{*}$

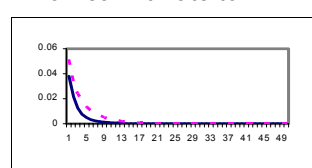

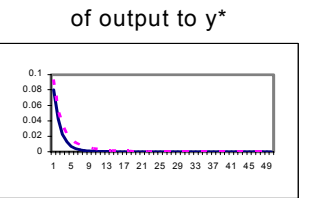

of d-inflation to $y^{*}$

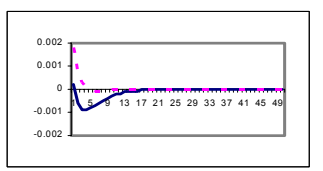

of cpi-inflation to $y^{*}$

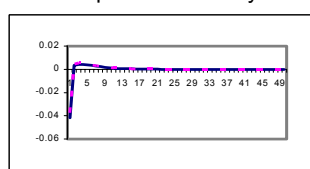

of nom. exc. rate to $y^{*}$

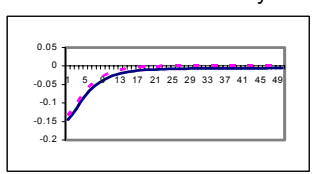

of real ex. rate to $y^{*}$

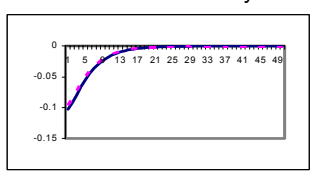

of nom. int. rate to $\mathrm{y}^{*}$

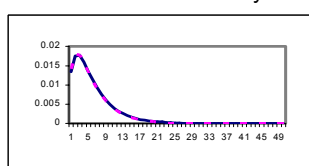

of real int. rate to $\mathrm{y}^{*}$

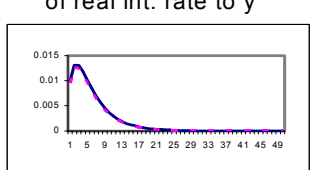

of output to $z$

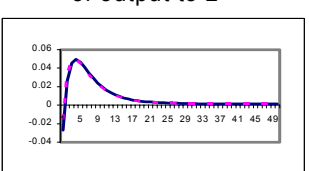

of d-inflation to $z$

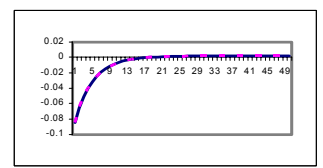

of cpi-inflation to $z$

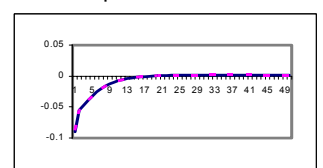

of nom. exc. rate to $z$

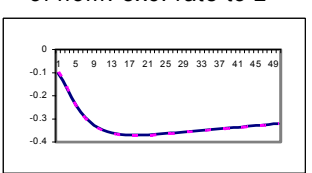

of real ex. rate to $z$

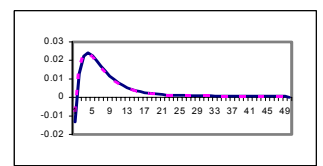

of nom. int. rate to $z$

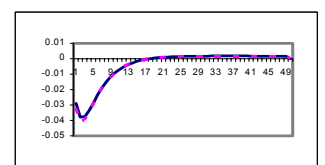

of real int. rate to $z$

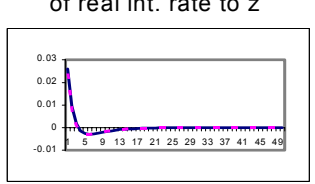

of output to i

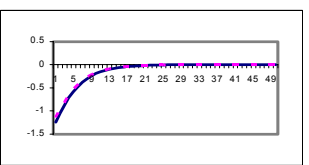

of d-inflation to i

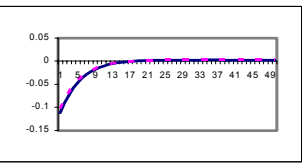

of cpi-inflation to i

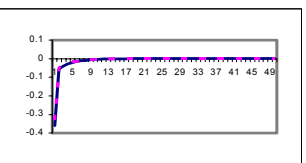

of nom. exc. rate to $\mathrm{i}$

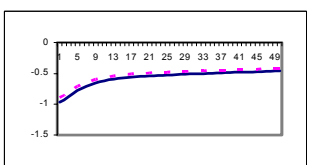

of real ex. rate to $\mathrm{i}$

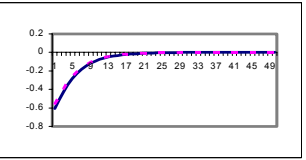

of nom. int. rate to $i$

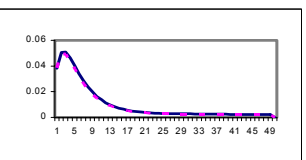

of real int. rate to $\mathrm{i}$

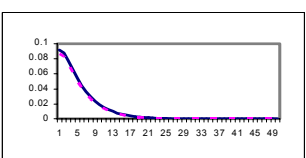

Note: The first column presents impulse-response functions to a $25 \mathrm{bps}$. Temporary innovations in the foreign interest rate; the second to a 1 percent foreign output shock; the third to a 1 percent total factor productivity shock; and the fourth to a 25 bps. temporary innovations in the domestic interest rate. The solid line corresponds to CPI inflation targeting and the dashed line to domestic inflation targeting. 


\section{Figure 4: CPI vs. Domestic Inflation Targeting: Managed Exchange Rate}
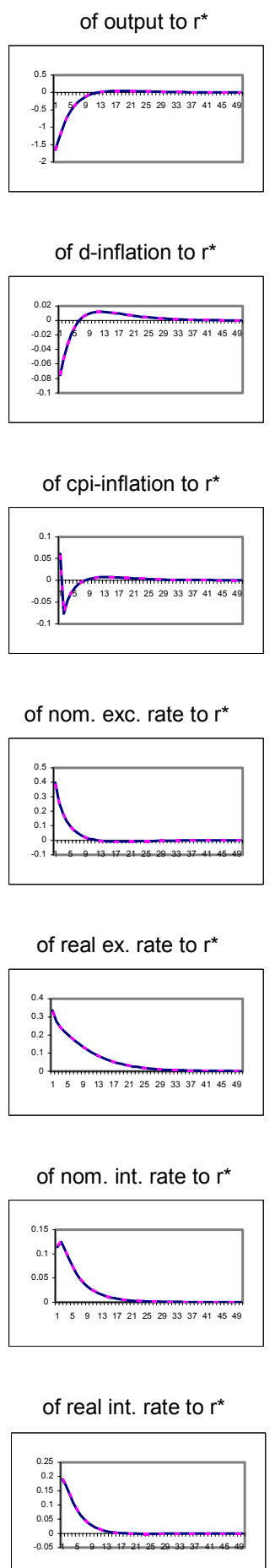

of output to $\mathrm{y}^{\star}$

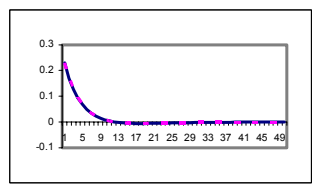

of d-inflation to $\mathrm{y}^{*}$

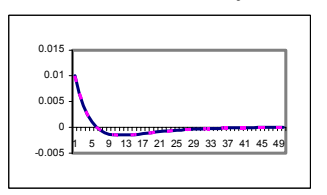

of cpi-inflation to $y^{*}$
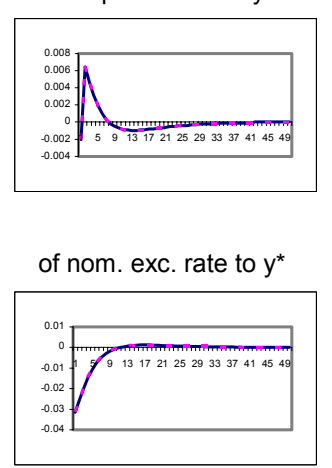

of real ex. rate to $y^{*}$

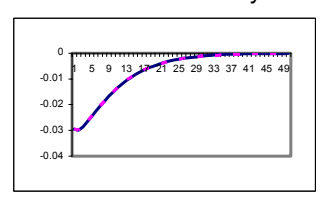

of nom. int. rate to $\mathrm{y}^{*}$

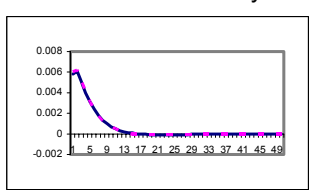

of real int. rate to $\mathrm{y}^{\star}$

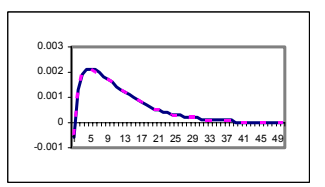

of output to $z$

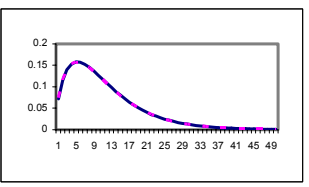

of d-inflation to $z$

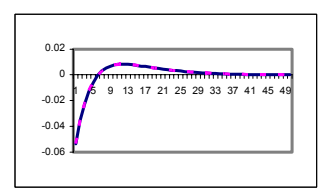

of cpi-inflation to z

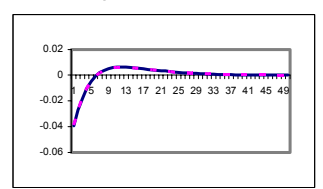

of nom. exc. rate to $z$

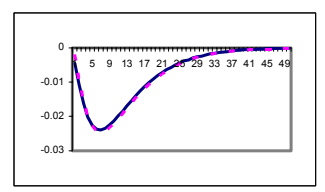

of real ex. rate to $z$

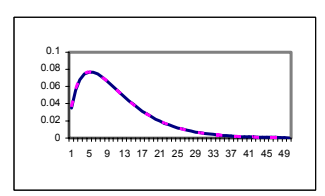

of nom. int. rate to $z$

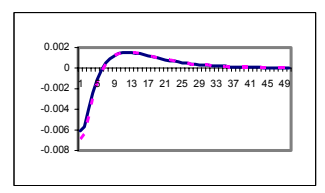

of real int. rate to $z$

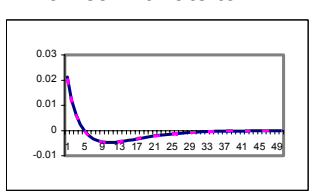

of output to i

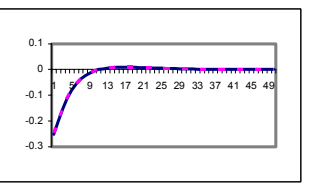

of d-inflation to

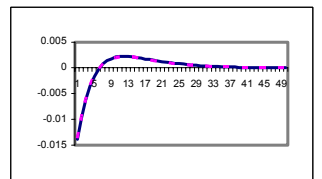

of cpi-inflation to i

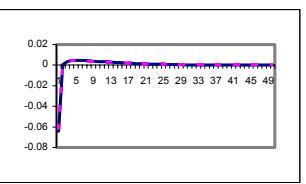

of nom. exc. rate to $i$

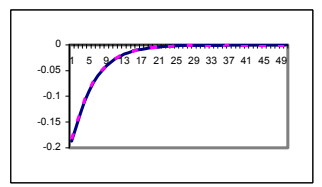

of real ex. rate to $i$

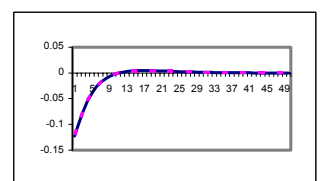

of nom. int. rate to $\mathrm{i}$

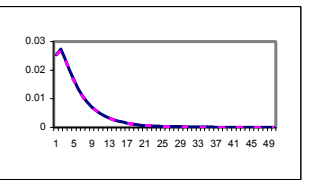

of real int. rate to $i$

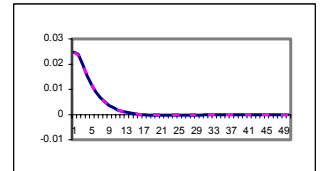

Note: The first column presents impulse-response functions to a $25 \mathrm{bps}$. Temporary innovations in the foreign interest rate; the second to a 1 percent foreign output shock; the third to a 1 percent total factor productivity shock; and the fourth to a 25 bps. temporary innovations in the domestic interest rate. The solid line corresponds to CPI inflation targeting and the dashed line to domestic inflation targeting. 
If the economy has a managed exchange rate, the distinction between CPI and domestic inflation targeting is not relevant, since volatility in all variables is equivalent. This result is obvious, because targeting the CPI is equivalent to targeting both domestic inflation and the nominal exchange rate; it is also equivalent to targeting domestic inflation with managed exchange rates.

Focus, then, on the flexible exchange rate case, considering the effects of a foreign interest rate innovation. (The same conclusions hold across different shocks.) Dynamic responses are similar to those in the previous subsection. The key result in this comparison is that for all shocks, targeting domestic inflation is preferable to targeting CPI inflation. The intuition is that the domestic inflation target allows the exchange rate to move more in response to disturbances, thereby stabilizing output to a greater degree. The variability of domestic inflation (obviously) and output is therefore lower under domestic inflation targeting, while the variability of the real exchange rate can be higher, though it need not be. The beneficial welfare impact of the former two always outweighs the welfare costs of higher real exchange rate volatility (when it exists), so that welfare losses are lower under domestic inflation targeting than under the CPI inflation targeting regime.

\section{Welfare Comparisons}

Social loss is larger under CPI inflation targeting than under domestic inflation targeting (see Table 2). In the flexible exchange rate case, which is the relevant regime for comparing CPI and domestic inflation targeting, the same conclusion holds, irrespective of the targeting case and source of the shock. ${ }^{22}$ A monetary policy that considers domestic inflation is far more stabilizing that one that takes CPI inflation into account in the inflation targeting regime.

\section{Flexible Versus Strict Inflation Targeting}

Flexible inflation targeting, in the nomenclature of Svensson (2000), occurs when a central bank seeks to stabilize output, inflation, and the exchange rate. By contrast, strict inflation targeting occurs when the monetary authority only attempts to stabilize inflation and the exchange rate without considering the effects on output. Figures 5 and 6 compare the impulse-response functions of flexible and strict inflation targeting under flexible and managed exchange rates, respectively.

${ }^{22}$ The only exception is in the case of strict inflation targeting in the presence of productivity shocks. In this case, however, the difference between the CPI and domestic inflation targeting is negligible. 


\section{Figure 5: Flexible vs. Strict CPI Inflation Targeting: Flexible Exchange Rate}
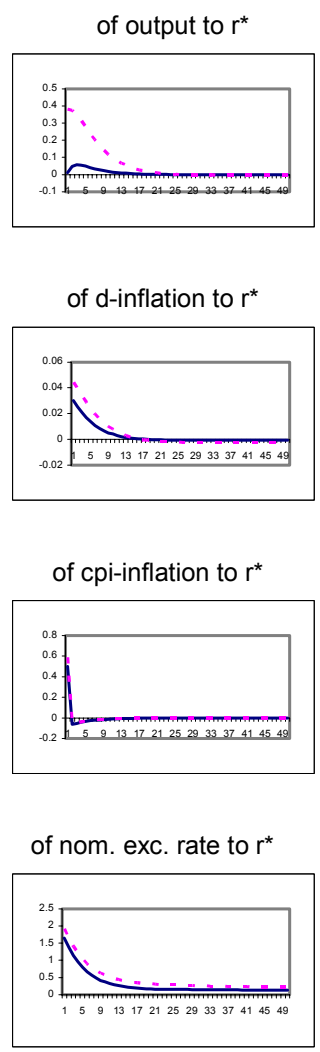

of real ex. rate to $r^{*}$

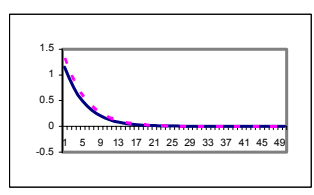

of nom. int. rate to $r^{\star}$

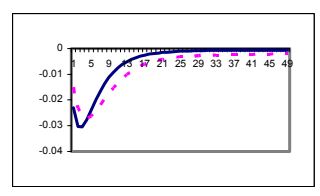

of real int. rate to $r^{*}$

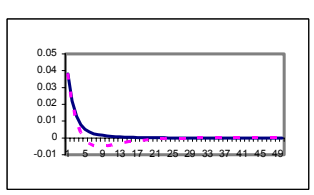

of output to $\mathrm{y}^{*}$

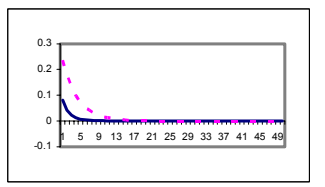

of d-inflation to $\mathrm{y}^{*}$

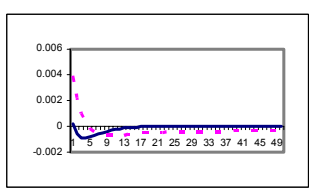

of cpi-inflation to $y^{*}$
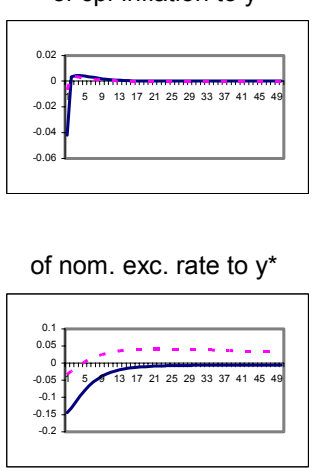

of real ex. rate to $y^{\star}$

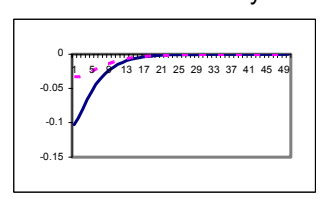

of nom. int. rate to $\mathrm{y}^{*}$

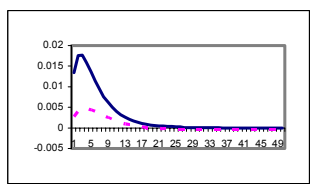

of real int. rate to $\mathrm{y}^{*}$

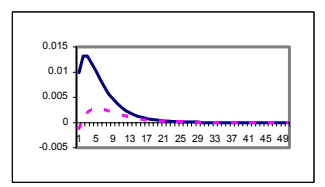

of output to $z$

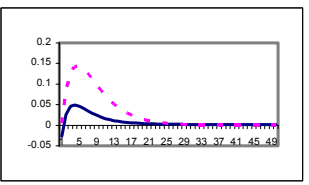

of d-inflation to $z$

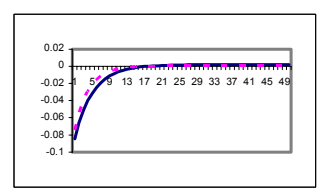

of cpi-inflation to z

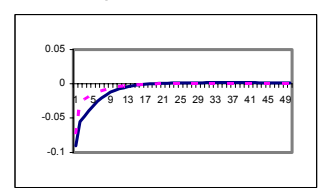

of nom. exc. rate to $z$

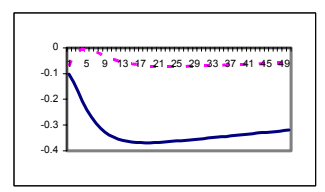

of real ex. rate to $z$

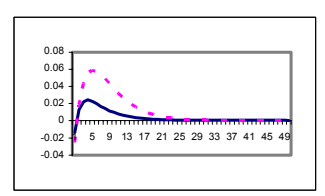

of nom. int. rate to $z$

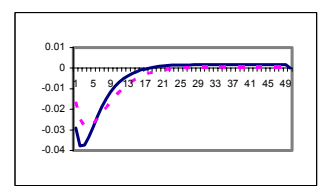

of real int. rate to $z$

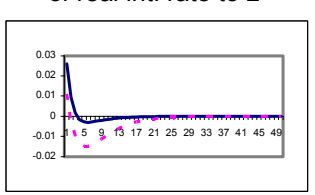

of output to $i$

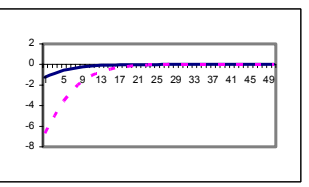

of d-inflation to i

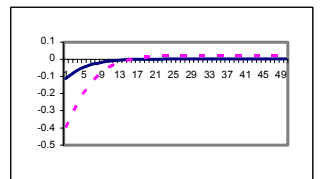

of cpi-inflation to i

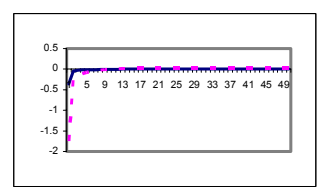

of nom. exc. rate to $i$

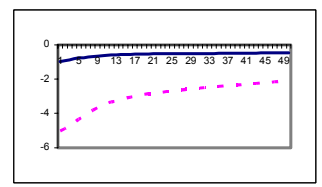

of real ex. rate to $\mathrm{i}$

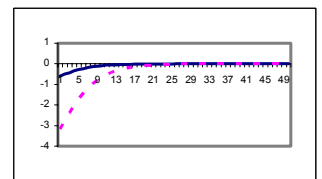

of nom. int. rate to $\mathrm{i}$

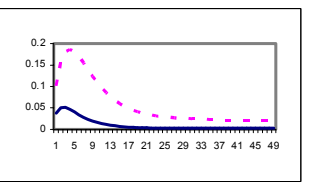

of real int. rate to $i$

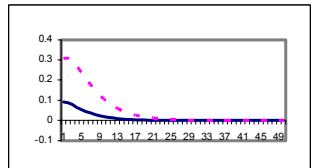

Note: The first column presents impulse-response functions to a $25 \mathrm{bps}$. Temporary innovations in the foreign interest rate; the second to a 1 percent foreign output shock; the third to a 1 percent total factor productivity shock; and the fourth to a 25 bps. temporary innovations in the domestic interest rate. The solid line corresponds to flexible CPI inflation targeting and the dashed line to strict CPI inflation targeting. 
Figure 6: Flexible vs. Strict Domestic Inflation Targeting: Flexible Exchange Rate

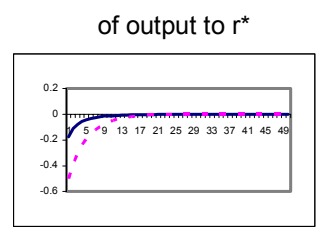

of d-inflation to $r^{*}$

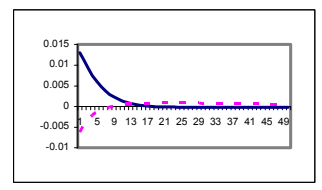

of cpi-inflation to $r^{*}$

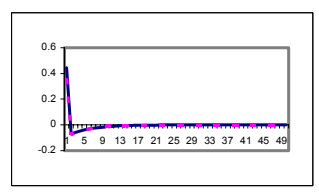

of nom. exc. rate to $r^{*}$

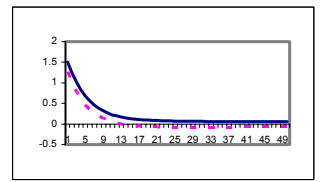

of real ex. rate to $r^{*}$

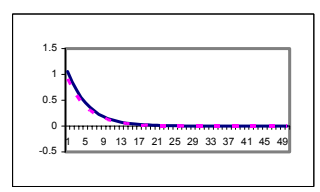

of nom. int. rate to $r^{\star}$

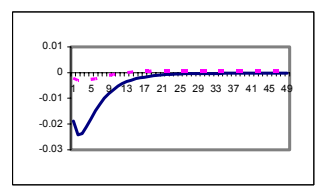

of real int. rate to $r^{*}$

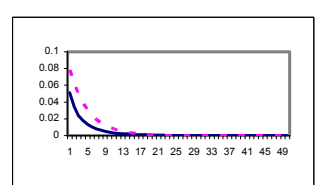

of output to $\mathrm{y}^{*}$

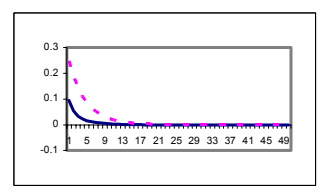

of d-inflation to $\mathrm{y}^{*}$

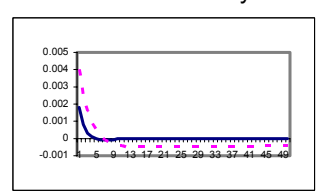

of cpi-inflation to $y^{*}$

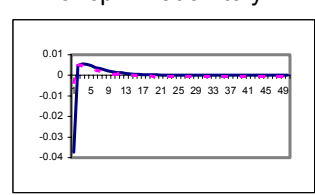

of nom. exc. rate to $y^{*}$

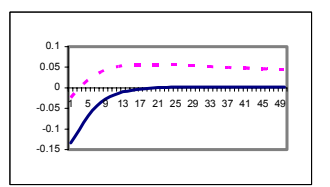

of real ex. rate to $\mathrm{y}^{*}$

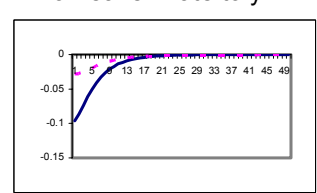

of nom. int. rate to $\mathrm{y}^{*}$

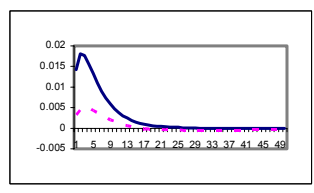

of real int. rate to $\mathrm{y}^{*}$

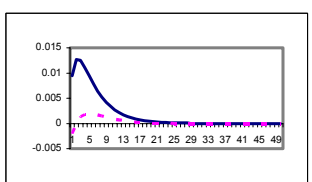

of output to $z$

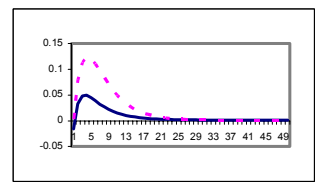

of d-inflation to $z$

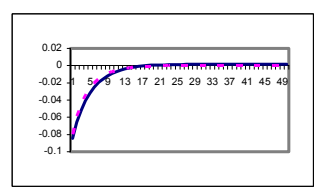

of cpi-inflation to $z$

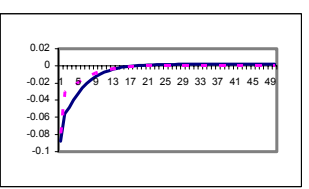

of nom. exc. rate to $z$

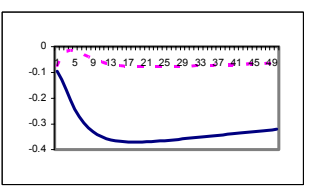

of real ex. rate to $z$

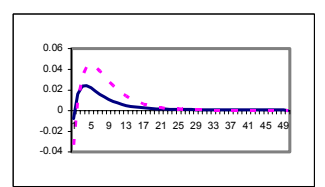

of nom. int. rate to $z$

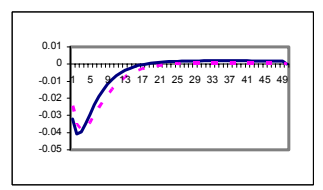

of real int. rate to $z$

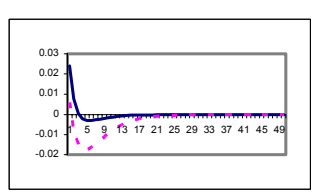

of output to $i$

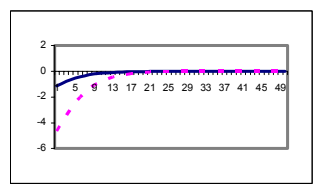

of d-inflation to i

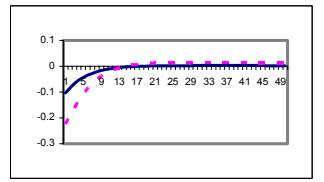

of cpi-inflation to i

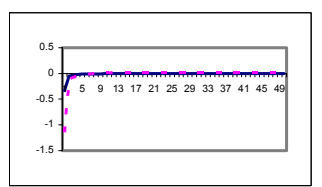

of nom. exc. rate to $i$

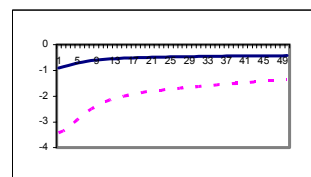

of real ex. rate to $\mathrm{i}$

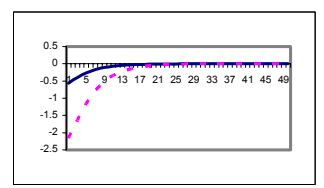

of nom. int. rate to $i$

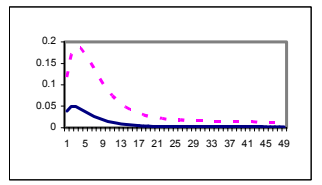

of real int. rate to $\mathrm{i}$

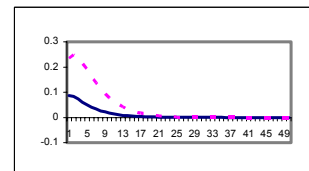

Note: The first column presents impulse-response functions to a 25 bps. Temporary innovations in the foreign interest rate; the second to a 1 percent foreign output shock; the third to a 1 percent total factor productivity shock; and the fourth to a 25 bps. temporary innovations in the domestic interest rate. The solid line corresponds to flexible domestic inflation targeting and the dashed line to strict domestic inflation targeting. 
A number of interesting results emerge from these figures. First, independent of the source of disturbance, output volatility is higher in the strict case than in the flexible case. Second, the results are ambiguous in terms of inflation stability and depend on the type of shock. For instance, if the source of disturbance is the domestic interest rate, flexible inflation targeting dominates strict inflation targeting. If there is a productivity shock, however, the impact on CPI and domestic inflation is higher under flexible inflation targeting. As Svensson (2000) points out, strict CPI inflation targeting relies on the use of the exchange rate channel to stabilize CPI inflation. The real exchange rate thus exhibits lower volatility under strict targeting than under the flexible case, and this results in higher volatility of output and domestic inflation. These differences decrease under managed exchange rates, since in this case the monetary authority seeks to stabilize the nominal exchange rate as well and hence introduces less adjustment to nominal interest rates and, in turn, less volatility in output and inflation.

\section{Welfare Comparisons}

As mentioned above, the analysis found mixed evidence regarding inflation volatility in the two cases. The conclusion is quite clear, however, with regard to the social loss, which combines inflation, domestic inflation, and real exchange rate volatility: social loss is lower under flexible inflation targeting than under strict inflation targeting (see Table 2).

\section{Conclusions}

This paper has developed a simple dynamic neo-Keynesian model of a small open economy in which inflation targeting plays a key role for monetary policy. In particular, the model is based on explicit utility and profit maximization, and explicit treatment of market structure. It includes a formal examination of the effects of different exchange rate regimes and inflation targets indicators, considering simple forecast-based monetary policy rules.

The main findings of this paper are that, depending on what shocks affect this economy, the effects of inflation targeting on output and inflation volatility depend crucially on the exchange rate regime and the inflation index being targeted. With regard to the exchange rate, the analysis concludes that the social loss is much higher under managed exchange rates than under flexible rates if there are foreign and real shocks, while for nominal shocks, the reverse is true. As far as the definition of the inflation targeting index is concerned, domestic inflation appears to outperform the CPI. Finally, and somewhat predictably, flexible inflation targeting is superior to strict inflation targeting.

These results, while suggestive, are subject to many caveats. Here three caveats are highlighted. First, the paper deals with simulation results. Conclusions about policy dominance and welfare consequences depend on a specific parameterization, and they should not be taken as general propositions. The model chooses parameters that conform to the Chilean economy, so the conclusions should have some empirical relevance. In addition, the paper experimented sufficiently with alternative parameterization to be confident that the results presented here are robust to relatively minor changes in assumptions. More work is clearly warranted, however, before making general policy recommendations. The second 
caveat has to do with those aspects the model omits. Much of the recent discussion of exchange rate policy in developing countries is concerned with the impact of exchange rate changes on financial variables: balance sheets, creditworthiness, risk premiums, and so forth. These effects become important when there are imperfections in financial markets; borrowing constraints and dollarization of liabilities are two that have received much recent attention. By contrast, the model here assumes not just well-functioning financial markets, but a full set of state-contingent assets. There are two justifications for this omission: it makes sense to analyze the performance of alternative rules in a more-or-less standard model before moving on to add financial imperfections, and work including financial imperfections in simpler macroeconomic models (see, for instance, Céspedes, Chang, and Velasco (2000); Chang and Velasco (2000)) shows that in spite of the presence of balance sheet effects and liability dollarization, the qualitative ranking of alternative monetary policies may be quite similar to that found in more standard sticky price models, such as the one studied here.

Finally, a natural next step is to base the analysis on the consumer's utility and not on ad-hoc welfare criteria. This important step implies not only aggregating the behavior of individuals, but also finding a tractable way to do so. This extension is not straightforward for a small open economy, since an additional variable - the terms of trade - makes it difficult to arrive at the quadratic formulation based on Taylor approximations developed by Woodford (1996, 2001) and Rotemberg and Woodford (1998a, 1998b). 


\section{Model Derivations}

\section{A. Aggregate Demand}

For all differentiated goods, market clearing implies

$$
Y_{t}(j)=C_{H, t}(j)+C_{H, t}^{*}(j) .
$$

Log-linearization around a steady state with balanced trade implies

$$
y_{t}(j)=(1-\gamma) c_{H, t}(j)+\gamma c_{H, t}^{*}(j)
$$

Define $Y_{t}(j) \equiv \int_{0}^{1} Y_{t}(j) d j$ as the aggregate domestic output. Then, log-linearizing this expression around the steady state, it transforms to $y_{t}=\int_{0}^{1} y_{t}(j) d j$. An analogous expression for $c_{H, t}(j)$ and $c_{H, t}^{*}(j)$ can be obtained to get the following expression: $y_{t}=(1-\gamma) c_{H, t}+\gamma c_{H, t}^{*}$. Combining this expression with a log-linearized version of equation (2), namely, $c_{t}=(1-\gamma) c_{H, t}+\gamma c_{F, t}$, it is obtained the following expression:

$$
\begin{aligned}
y_{t} & =(1-\gamma) c_{t}+\gamma c_{t}^{*}+\gamma \eta(2-\gamma) q_{t} \\
& =(1-\gamma) c_{t}+\gamma c_{t}^{*}+\gamma \eta(2-\gamma)\left(s_{t}+p_{t}^{*}-p_{H, t}\right) .
\end{aligned}
$$

Finally, assuming that $u(C)=C^{1-\sigma} /(1-\sigma)$ and using the log-linearization version of the Euler equation (7), an expression for the domestic output gap is obtained (equation (16) in the main text):

$$
x_{t}=E_{t}\left[x_{t+1}\right]+\phi_{\pi} E_{t}\left[\pi_{H, t+1}\right]-\phi_{s}\left(E_{t}\left[s_{t+1}\right]-s_{t}\right)-\frac{1}{\sigma} i_{t}-\left(1-\rho_{z}\right) z_{t}+\gamma\left(1-\rho_{y^{*}}\right) y_{t}^{*},
$$

where $x_{t}$ is the domestic output gap, $\phi_{\pi}=[(1-\gamma) / \sigma+\gamma \eta(2-\gamma)]$, $\phi_{s}=\gamma[\eta(2-\gamma)-1 / \sigma], 0 \leq \rho_{z} \leq 1$, and $0 \leq \rho_{y^{*}} \leq 1$.

\section{B. Aggregate Supply}

The first order necessary condition of the firm is:

$E_{t}\left[\sum_{k=0}^{\infty} \alpha^{k} \beta^{k} \Lambda_{t+k}\left\langle\frac{p_{H, t}(j)}{P_{H, t+k}}-\frac{\theta}{\theta-1} \frac{W_{t+k}}{P_{H, t+k}} \frac{V^{\prime}\left\{\left[p_{H, t}(j) / P_{H, t+k}\right]^{-\theta} C_{H, t+k}^{A}\right\}}{\tilde{Z}_{t+k}}\right\rangle\left[\frac{p_{H, t}(j)}{P_{H, t+k}}\right]^{-\theta} C_{H, t+k}^{A}\right]=0$ 
Define $G_{t} \equiv p_{H, t}(j) / P_{H, t}, \Pi_{H, t} \equiv P_{H, t} / P_{H, t-1} \quad$ and $\zeta \equiv \theta /(\theta-1)$, then

$$
E_{t}\left[\sum_{k=0}^{\infty} \alpha^{k} \beta^{k} \Lambda_{t+k}\left\{\frac{G_{t}}{\prod_{s=1}^{k} \Pi_{H, t+s}}-\zeta \frac{W_{t+k}}{P_{H, t+k}} \frac{V^{\prime}\left[\left(G_{t} / \prod_{s=1}^{k} \Pi_{H, t+s}\right)^{-\theta} C_{H, t+k}^{A}\right]}{Z_{t+k}}\right\}\left(\frac{G_{t}}{\prod_{s=1}^{k} \Pi_{H, t+s}}\right)^{-\theta} C_{H, t+k}^{A}\right]=0
$$

In equilibrium, each consumer-producer that chooses a new price in period $t$ will choose the same new price and the same level of output. Then the (aggregate) price of domestic goods will obey

$$
p_{H, t}=\left[\alpha p_{H, t-1}+(1-\alpha) p_{H, t}(j)\right]^{1 /(1-\theta)} .
$$

Therefore,

$$
\Pi_{H, t}=\alpha^{1 /(1-\theta)}\left[1-(1-\alpha) G_{t}^{1-\theta}\right]^{1 /(\theta-1)} .
$$

Log-linearizing around the steady state, it is allowed bounded fluctuations in $C_{H, t}^{A}, \Pi_{H, t}, \mathrm{G}_{t}$, $\Lambda_{t}$, and $W_{t} / \mathrm{P}_{H, t}$ around a steady state $\left(y^{d}, 1,1, \Lambda\right.$, and 1$)$. Thus,

$$
\begin{gathered}
v_{t}^{\prime}=\xi y_{t}^{d}, \\
w_{t}=(1-\delta) p_{H, t}+\delta p_{t}^{*}, \text { and } \\
\pi_{H, t}=\frac{1}{(\theta-1)} \frac{-(1-\alpha)}{[1-(1-\alpha)]}(1-\theta) g_{t}=\frac{1-\alpha}{\alpha} g_{t},
\end{gathered}
$$

where $\xi>0$ is the elasticity of $V^{\prime}$ with respect to $Y_{t}^{d}$ and $1 \geq \delta \geq 0$ is the share of the foreign good in the composite input.

$$
\begin{gathered}
E_{t}\left[\sum_{k=0}^{\infty} \alpha^{k} \beta^{k}\left\{g_{t}-\sum_{s=1}^{k} \pi_{H, t+s}-w_{t+k}+p_{H, t+k}-\xi\left[y_{t+k}^{d}-\theta\left(g_{t}-\sum_{s=1}^{k} \pi_{H, t+s}\right)\right]+z_{t+k}\right\}\right]=0, \\
E_{t}\left[\sum_{k=0}^{\infty} \alpha^{k} \beta^{k}\left[(1+\xi \theta)\left(g_{t}-\sum_{s=1}^{\infty} \pi_{H, t+s}\right)-\xi y_{t+k}^{d}-\gamma q_{t+k}+z_{t+k}\right]\right]=0 .
\end{gathered}
$$


However, $\sum_{k=0}^{\infty} \alpha^{k} \beta^{k} \sum_{\tau=1}^{k} \pi_{H, t+s}=\sum_{\tau=1}^{\infty} \pi_{H, t+s} \sum_{k=\tau}^{\infty} \alpha^{k} \beta^{k}=\sum_{\tau=1}^{\infty} \pi_{H, t+\tau} \frac{\alpha^{\tau} \beta^{\tau}}{1-\alpha \beta}$, and this is equal to $\frac{1}{1-\alpha \beta} \sum_{k=1}^{\infty} \alpha^{k} \beta^{k} \pi_{H, t+k}$

Then, it is possible to rewrite

$$
E_{t}\left[\frac{1+\xi \theta}{1-\alpha \beta} g_{t}-\frac{1+\xi \theta}{1-\alpha \beta} \sum_{k=1}^{\infty} \alpha^{k} \beta^{k} \pi_{H, t+k}-\sum_{k=0}^{\infty} \alpha^{k} \beta^{k}\left(\xi y_{t+k}^{d}+\gamma q_{t+k}-\widetilde{z}_{t+k}\right)\right]=0 .
$$

Thus,

$$
\begin{gathered}
g_{t}=E_{t}\left[\sum_{k=1}^{\infty} \alpha^{k} \beta^{k} \pi_{H, t+s}+\frac{1-\alpha \beta}{1+\xi \theta} \sum_{k=0}^{\infty} \alpha^{k} \beta^{k}\left(\xi y_{t+k}^{d}+\gamma q_{t+k}-z_{t+k}\right)\right], \\
g_{t}=\mathrm{E}_{t}\left\{\alpha \beta \pi_{H, t+1}+\frac{1-\alpha \beta}{1+\xi \theta}\left[\xi y_{t+k}^{d}+\gamma s_{t+k}-z_{t+k}\right]+\alpha \beta \mathrm{E}_{t}\left[x_{t+1}\right]\right\},
\end{gathered}
$$

but $\pi_{H, t}=\frac{1-\alpha}{\alpha} g_{t}$. Hence,

$$
\frac{\alpha}{1-\alpha} \pi_{H, t}=E_{t}\left[\alpha \beta \pi_{H, t+1}+\frac{1-\alpha \beta}{1+\xi \theta}\left(\xi y_{t+k}^{d}+\gamma q_{t+k}-\widetilde{z}_{t+k}\right)+\alpha \beta \frac{\alpha}{1-\alpha} E_{t}\left[\pi_{H, t+1}\right]\right],
$$

and finally

$$
\pi_{H, t}=\beta E_{t}\left[\pi_{H, t+1}\right]+\lambda_{x} x_{t}+\lambda_{q} q_{t},
$$

where $z_{t}=\xi \widetilde{z}_{t}$, and hence output gap is defined as $x_{t}=y_{t}^{d}-z_{t}$. Recalling that $q_{t}=s_{t}+p_{t}^{*}-p_{H, t}$, an expression for the aggregate supply is derived (equation (17) in the main text):

$$
\pi_{H, t}=\beta E_{t}\left[\pi_{H, t+1}\right]+\lambda_{x} x_{t}+\lambda_{q}\left(s_{t}+p_{t}^{*}-p_{H, t}\right)
$$

where $\lambda_{x}=\frac{(1-\alpha)(1-\alpha \beta)}{\alpha(1+\xi \theta)} \xi$ and $\lambda_{q}=\lambda_{x} \gamma$ 


\section{SUPPLEMENTAL TABLES}

Table A.1. Unconditional Standard Deviations: Foreign Interest Rate Shock

\begin{tabular}{|c|c|c|c|c|c|c|}
\hline Targeting case & Output & $\begin{array}{c}\text { Domestic } \\
\text { inflation }\end{array}$ & $\begin{array}{c}C P I \\
\text { inflation }\end{array}$ & $\begin{array}{c}\text { Real } \\
\text { exchange } \\
\text { rate }\end{array}$ & $\begin{array}{c}\text { Nominal } \\
\text { interest } \\
\text { rate }\end{array}$ & $\begin{array}{c}\text { Real } \\
\text { interest } \\
\text { rate }\end{array}$ \\
\hline \multicolumn{7}{|c|}{ Flexible CPI inflation targeting } \\
\hline Flexible exchange rate & 0.8466 & 0.0957 & 0.6972 & 2.4209 & 0.1419 & 0.7433 \\
\hline Managed exchange rate & 2.4270 & & 0.1651 & 0.8473 & 0.5965 & 0.7073 \\
\hline \multicolumn{7}{|c|}{ Strict CPI inflation targeting } \\
\hline Flexible exchange rate & 4.2840 & 0.2026 & 1.1340 & 4.0510 & 0.0863 & 1.1273 \\
\hline Managed exchange rate & 2.9132 & 0.1248 & 0.1254 & 0.6447 & 0.6698 & 0.7534 \\
\hline \multicolumn{7}{|c|}{ Flexible domestic inflation targeting } \\
\hline Flexible exchange rate & 0.3504 & 0.0712 & 0.6314 & 2.1916 & 0.1866 & 0.7019 \\
\hline Managed exchange rate & 2.4483 & 0.1248 & 0.1615 & 0.8383 & 0.6013 & 0.7107 \\
\hline \multicolumn{7}{|c|}{ Strict domestic inflation targeting } \\
\hline Flexible exchange rate & 0.9913 & 0.0314 & 0.7161 & 2.5534 & 0.0794 & 0.7402 \\
\hline Managed exchange rate & 2.9289 & 0.1254 & 0.1227 & 0.6387 & 0.6744 & 0.7572 \\
\hline
\end{tabular}

Table A.2. Unconditional Standard Deviations: Foreign Output Shock

\begin{tabular}{|c|c|c|c|c|c|c|}
\hline Targeting case & Output & $\begin{array}{c}\text { Domestic } \\
\text { inflation }\end{array}$ & $\begin{array}{c}C P I \\
\text { inflation }\end{array}$ & $\begin{array}{l}\text { Real } \\
\text { exchange } \\
\text { rate }\end{array}$ & $\begin{array}{c}\text { Nominal } \\
\text { interest } \\
\text { rate }\end{array}$ & $\begin{array}{c}\text { Real } \\
\text { interest } \\
\text { rate }\end{array}$ \\
\hline \multicolumn{7}{|c|}{ Flexible CPI inflation targeting } \\
\hline Flexible exchange rate & 0.0950 & 0.0021 & 0.0429 & 0.1657 & 0.0402 & 0.0513 \\
\hline Managed exchange rate & 0.3337 & 0.0163 & 0.0104 & 0.0853 & 0.0116 & 0.0070 \\
\hline \multicolumn{7}{|c|}{ Strict CPI inflation targeting } \\
\hline Flexible exchange rate & 0.3536 & 0.0060 & 0.0102 & 0.0794 & 0.0123 & 0.0099 \\
\hline Managed exchange rate & 0.3988 & 0.0163 & 0.0113 & 0.0633 & 0.0011 & 0.0108 \\
\hline \multicolumn{7}{|c|}{ Flexible domestic inflation targeting } \\
\hline Flexible exchange rate & 0.1327 & 0.0036 & 0.0367 & 0.1745 & 0.0394 & 0.0439 \\
\hline Managed exchange rate & 0.3329 & 0.0163 & 0.0105 & 0.0854 & 0.0120 & 0.0071 \\
\hline \multicolumn{7}{|c|}{ Strict domestic inflation targeting } \\
\hline Flexible exchange rate & 0.3751 & 0.0078 & 0.0120 & 0.0700 & 0.0140 & 0.0073 \\
\hline Managed exchange rate & 0.3976 & 0.0163 & 0.0113 & 0.0634 & 0.0015 & 0.0105 \\
\hline
\end{tabular}


Table A.3. Unconditional Standard Deviations: Productivity Shock

\begin{tabular}{lcccccc}
\hline \multicolumn{2}{c}{ Output } & $\begin{array}{c}\text { Domestic } \\
\text { inflation }\end{array}$ & $\begin{array}{c}\text { CPI } \\
\text { inflation }\end{array}$ & $\begin{array}{c}\text { Real } \\
\text { exchange } \\
\text { rate }\end{array}$ & $\begin{array}{c}\text { Nominal } \\
\text { interest } \\
\text { rate }\end{array}$ & $\begin{array}{c}\text { Real } \\
\text { interest } \\
\text { rate }\end{array}$ \\
\hline $\begin{array}{l}\text { Flexible CPI inflation targeting } \\
\text { Flexible exchange rate }\end{array}$ & 0.1181 & 0.1361 & 0.1341 & 0.0577 & 0.0860 & 0.0944 \\
Managed exchange rate & 0.4529 & 0.0697 & 0.0523 & 0.2212 & 0.0098 & 0.0462 \\
\hline $\begin{array}{l}\text { Strict CPI inflation targeting } \\
\text { Flexible exchange rate }\end{array} \quad 0.3792$ & 0.1095 & 0.0879 & 0.1571 & 0.0746 & 0.0841 \\
Managed exchange rate & 0.5585 & 0.0705 & 0.0490 & 0.2727 & 0.0046 & 0.0466 \\
\hline $\begin{array}{l}\text { Flexible domestic inflation targeting } \\
\text { Flexible exchange rate }\end{array} \quad 0.1600$ & 0.1153 & 0.1108 & 0.0781 & 0.0699 & 0.0781 \\
Managed exchange rate & 0.4526 & 0.0698 & 0.0522 & 0.2210 & 0.0111 & 0.0453 \\
\hline $\begin{array}{l}\text { Strict domestic inflation targeting } \\
\text { Flexible exchange rate }\end{array} \quad 0.2836$ & 0.1173 & 0.0948 & 0.1055 & 0.0877 & 0.0876 \\
Managed exchange rate & 0.5590 & 0.0704 & 0.0486 & 0.2730 & 0.0063 & 0.0453 \\
\hline
\end{tabular}

Table A.4. Unconditional Standard Deviations: Domestic Interest Rate Shock

\begin{tabular}{|c|c|c|c|c|c|c|}
\hline Targeting case & Output & $\begin{array}{l}\text { Domestic } \\
\text { inflation }\end{array}$ & $\begin{array}{c}\text { CPI } \\
\text { inflation }\end{array}$ & $\begin{array}{c}\text { Real } \\
\text { exchange } \\
\text { rate }\end{array}$ & $\begin{array}{c}\text { Nominal } \\
\text { interest } \\
\text { rate }\end{array}$ & $\begin{array}{c}\text { Real } \\
\text { interest } \\
\text { rate }\end{array}$ \\
\hline \multicolumn{7}{|c|}{ Flexible CPI inflation targeting } \\
\hline Flexible exchange rate & 4.4134 & 0.3791 & 0.7371 & 2.1553 & 0.2455 & 0.8113 \\
\hline Managed exchange rate & 0.7382 & 0.0452 & 0.1323 & 0.3605 & 0.1102 & 0.1581 \\
\hline \multicolumn{7}{|c|}{ Strict CPI inflation targeting } \\
\hline Flexible exchange rate & 25.4384 & 1.4824 & 3.5524 & 12.0738 & 1.1190 & 3.7836 \\
\hline Managed exchange rate & 0.9111 & 0.0453 & 0.1540 & 0.4449 & 0.1361 & 0.1861 \\
\hline \multicolumn{7}{|c|}{ Flexible domestic inflation targeting } \\
\hline Flexible exchange rate & 3.7255 & 0.3441 & 0.6634 & 1.8194 & 0.2724 & 0.7268 \\
\hline Managed exchange rate & 0.7368 & 0.0452 & 0.1321 & 0.3598 & 0.1098 & 0.1579 \\
\hline \multicolumn{7}{|c|}{ Strict domestic inflation targeting } \\
\hline Flexible exchange rate & 16.6473 & 0.9681 & 2.3801 & 7.7738 & 0.8745 & 2.5862 \\
\hline Managed exchange rate & 0.8890 & 0.0442 & 0.1505 & 0.4342 & 0.1130 & 0.1820 \\
\hline
\end{tabular}




\section{REFERENCES}

Ball, Lawrence, 1999, "Policy Rules for Open Economies," in Monetary Policy Rules, ed. by J. Taylor (Chicago, Illinois: University of Chicago Press).

Batini, Nicoletta, and Andrew G. Haldane, 1998, "Forward-Looking Rules for Monetary Policy,” NBER Working Paper No. 6543 (Cambridge, Massachusetts: National Bureau of Economic Research).

Benigno, Pierpaolo, 2000, “Optimal Monetary Policy in a Currency Area" (unpublished; Princeton, New Jersey: Princeton University).

Benigno, Pierpaolo, and Gianluca Benigno, 2001, "Price Stability in Open Economies" (unpublished; New York: New York University).

Bernanke, Ben, Mark Gertler, and Simon Gilchrist, 1999, "The Financial Accelerator in a Quantitative Business Cycle Framework," in Handbook of Macroeconomics, ed. by J. Taylor and M. Woodford (Amsterdam: North-Holland).

Bernanke, Ben, Thomas Laubach, Frederick Mishkin, and Adam Posen, 1999, "Inflation Targeting: Lessons from the International Experience." (Princeton, New Jersey: Princeton University Press).

Blanchard, Olivier, and Charles Kahn, 1980, "The Solution of Linear Difference Models under Rational Expectations," Econometrica, Vol. 48, No. 5, pp. 1305-11.

Calvo, Guillermo, 1983, "Staggered Prices in a Utility-Maximizing Framework," Journal of Monetary Economics, Vol. 12, No. 3, pp. 383-98.

Céspedes, Luis Felipe, Roberto Chang, and Andrés Velasco, 2000, "Balance Sheets and Exchange Rate Policy," NBER Working Paper 7840 (Cambridge, Massachusetts: National Bureau of Economic Research).

Chang, Roberto, and Andrés Velasco, 2000, "Liquidity Crises in Emerging Markets," NBER Working Paper 7272 (Cambridge, Massachusetts: National Bureau of Economic Research).

Clarida, Richard, Jordi Galí, and Mark Gertler, 1998, "Monetary Policy Rules in Practice: Some International Evidence," European Economic Review, Vol. 42, No. 6, pp. 1033-68.

— 1999, "The Science of Monetary Policy: A New Keynesian Perspective," Journal of Economic Literature, Vol. 37, No. 4, pp. 1661-707.

— 2000, "Monetary Policy Rules and Macroeconomic Stability: Evidence and Some Theory," Quarterly Journal of Economics, Vol. 115, No. 1, pp. 147-80. 
Cole, Harold L., and Maurice Obstfeld, 1991, "Commodity Trade and International Risk Sharing: How Much Do Financial Markets Matter?” Journal of Monetary Economics, Vol. 28, No. 1, pp. 3-24.

Dixit, Avinash K., and Joseph E. Stiglitz, 1977, "Monopolistic Competition and Optimum Product Diversity," American Economic Review, Vol. 67, No. 3, pp. 297-308.

Fischer, Stanley, 1977, "Stability and Exchange Rate Systems in a Monetarist Model of the Balance of Payments," in The Political Economy of Monetary Reform, ed. by R. Aliber (Montclair, New Jersey: Allanheld, Osmun and Co.)

Flood, Robert, 1979, "Capital Mobility and the Choice of Exchange Rate System," International Economic Review, Vol. 20, No. 2, pp. 405-16.

Galí, Jordi, and Tommaso Monacelli, 2002, "Optimal Monetary Policy and Exchange Rate Volatility in a Small Open Economy" (unpublished; Chestnut Hill, Massachusetts: Department of Economics, Boston College).

Ghironi, Fabio, and Alessandro Rebucci, 2001, "Monetary Rules for Emerging Market Economies," Working Paper 476, Economics Department, Boston College.

Goodfriend, Marvin, and Robert G. King, 1997, "The New Neoclassical Synthesis," in NBER Macroeconomics Annual, ed. by B. Bernanke and J. Rotemberg (Cambridge: MIT Press).

Jadresic, Esteban, 1999, "Inflation Targeting and Output Stability," IMF Working Paper 99/61 (Washington: International Monetary Fund).

King, Robert, and Alexander Wolman, 1996, "Inflation Targeting in a St. Louis Model of the 21st Century," Federal Reserve Bank of St. Louis Review, Vol. 78, No. 3, pp. 83-107.

Lane, Philip R., 2001, “The New Open Economy Macroeconomics: A Survey," Journal of International Economics, Vol. 54, No. 2, pp. 235-66.

Leitemo, Kai, 1999, "Inflation Targeting Strategies in Small Open Economies" (unpublished; University of Oslo).

Masson, Paul, Miguel A. Savastano, and Sunil Sharma, 1997, "The Scope for Inflation Targeting in Developing Countries," IMF Working Paper 97/130 (Washington: International Monetary Fund).

McCallum, Bennett T., and Edward Nelson, 1999, "Nominal Income Targeting in an OpenEconomy Optimizing Model," Journal of Monetary Economics, Vol. 43, No. 3, pp. $553-78$. 
Monacelli, Tommaso, 2000, "Relinquishing Monetary Independence" (unpublished; Chestnut Hill, Massachusetts: Department of Economics, Boston College).

Morandé, Felipe, 2001, “Una Década de Metas de Inflación en Chile: Desarrollos, Lecciones y Desafíos," Economía Chilena, Vol. 4, No. 1, pp. 35-62.

Obstfeld, Maurice, and Kenneth Rogoff, 1995, "Exchange Rate Dynamics Redux," Journal of Political Economy, Vol. 103, No. 3, pp. 624-60.

Parrado, Eric, 2000, "Monetary Policy Rules in a Small Open Economy: The Case of Chile" (unpublished; New York: New York University).

Parrado, Eric, and Andrés Velasco, 2002, "Optimal Interest Rate Policy in a Small Open Economy,” NBER Working Paper No. 8721 (Cambridge, Massachusetts: National Bureau of Economic Research).

Poole, 1970, "Optimal Choice of Monetary Policy Instruments in a Simple Stochastic Macro Model," Quarterly Journal of Economics, Vol. 84, No. 2, pp. 197-216.

Rotemberg, Julio J., and Michael Woodford, 1998a, “An Optimization Based Econometric Framework for the Evaluation of Monetary Policy," in NBER Macroeconomics Annual 1997, ed. by Ben S. Bernanke and Julio J. Rotemberg (Cambridge, Massachusetts: MIT Press), pp. 297-346.

- 1998b, "Interest-Rate Rules in an Estimated Sticky Price Model," in Monetary Policy Rules, ed. by John B. Taylor (Chicago, Illinois: University of Chicago Press), pp. 57-119.

Svensson, Lars E.O., 1999, "Inflation Targeting as a Monetary Policy Rule," Journal of Monetary Economics, Vol. 43, No. 3, pp. 607-654.

— 2000, “Open Economy Inflation Targeting," Journal of International Economics, Vol. 50, No. 1, pp. 155-83.

Woodford, Michael, 1996, "Control of the Public Debt: A Requirement for Price Stability," NBER Working Paper 5684 (Cambridge, Massachusetts: National Bureau of Economic Research).

—_ 1999, “Optimal Monetary Policy Inertia,” NBER Working Paper 7261 (Cambridge, Massachusetts: National Bureau of Economic Research).

— , 2001, "Inflation Stabilization and Welfare," NBER Working Paper 8071 (Cambridge, Massachusetts: National Bureau of Economic Research). 